\title{
Archaeological investigations at Tepe Hissar-Damghan using Gravity and Magnetics methods
}

\author{
Behzad Sarlak ${ }^{1}$, Hamid Aghajani ${ }^{2}$ \\ ${ }^{1} M S c$ Geophysics, Faculty of Mining, Petroleum \& Geophysics Engineering, Shahrood University of \\ Technology, Shahrood, IRAN \\ ${ }^{2}$ Associate Professor, Faculty of Mining, Petroleum \& Geophysics Engineering, Shahrood University of \\ Technology, Shahrood, IRAN
}

\begin{abstract}
Research and exploration of the remaining relics from the past has special importance in identifying the date, history and the identity of a country. Development and the advancement of human knowledge have offered new methods for the detection archaeological sites that by using them without the need for excavation and destruction of antiquities can be found useful information. Today, the nondestructive geophysical methods such as gravimetry and Magnetometry used to detect the archaeological discoveries without harmful environmental effects that only use natural properties of the subsurface material. For archeology studying, the target is detection of sub-surface structures which was made in the enceinte. But here it's possible was covered by some overburden such as alluvium. The gravity method is based on density contrast between the anomalous body (walls and chambers) and the host deposits and environments of them. While, in magnetic survey we use contrast of magnetization in between the environment and anomalous bodies, which is caused by natural factors or human activities such as metal products, building materials and cavities are filled. In this paper; to investigate the subsurface structures of walls and rooms in a part of the Teppe-Hissar archaeological site in Damghan, the gravity and magnetic data were used. In order to this work, the gravity and magnetic data measured in a regular grid in the desired area and then after do corrections such as instrument drift correction, free air and slab Bougure, latitude and terrain corrections on gravity data and the daily correction and Reduction to pole (RTP) correction on the magnetic data, the gravity and magnetic anomalies map were obtained. When the data quality permits, a range of highpass filters, such as downward continuation or vertical derivatives, can be applied to bring out fine detail. Also, In order to separate the residual anomaly from regional we used trend surface method. Local phase filters provide an alternative approach but conventional phase functions need to be unwrapped to remove phase ambiguity. Therefore, detection of the boundary of chambers or walls and the horizontal location of sources can be obtained from derivative based filters such as the horizontal gradient magnitude, tiltangle, theta-map, Laplacian and tangent hyperbolic. Since the tilt angle is based on a ratio of derivatives, it enhances large and small amplitude anomalies well. The results show that the tilt angle is effective in balancing the amplitudes of the different anomalies, but it is not primarily an edge-detection filter. The theta map uses the analytic signal amplitude to normalize the total horizontal derivative. The amplitude of the response of this filter from the deeper and shallow source bodies is similar, although the response from the deeper bodies is rather diffuse. The hyperbolic tilt angle (HTA) filter uses of the real part of the hyperbolic tangent function in the tilt angle calculation achieved better delineation of the edges of the anomalous body than the other filters we use here. The maximum value of the HTA gives location of the body edges. Normalized Derivatives Ratio (NDR), a new edge-detection filter, is based on ratios of the derivatives orthogonal to the horizontal of the field. The NDR is demonstrated using synthetic
\end{abstract}

*Corresponding author: haghajani@shahroodut.ac.ir 


\section{JOURNAL OF RESEARCH ON ARCHAEOMETRY}

and real gravity and magnetic data from an archaeology site, Tepe-Hissar. Compared with other filters, the NDR filter produces more detailed results as can see that the separation and detection walls and chambers have a high compliance with the results of excavations carried out. The results of these methods with the results of excavations carried out in the last few decades are highly adaptable, as it can be, according to the results of drilling, subsurface structures such as streets, walls or houses on the data obtained by gravity and magnetic survey. The information and data from these methods in an ancient area can be used as a basic plan by archaeologists for the archaeological exploration and excavation depth of field.

Keywords: Archaeometry, Gravity and Magnetic, Edge detection, Fuzzy filters, Teppe-Hissar. 


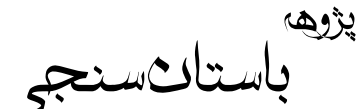

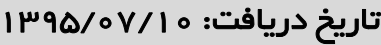

مقاله يُزوهشى

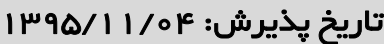

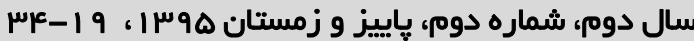

\section{بر رسىهاى باستانسنجى در تِهحار دامغان با استفاده از روشهاى كر انى سنجى و مغناطيس بهزاد سرلك'، حميد آقاجانى "}

1. كارشناس ارشد زئوفيزيك (كرانىسنجى)، دانشكده معلن، نفت و زُئوفيزيك، دانشكاه صنعتى شاهرود، شاهرود، ايران

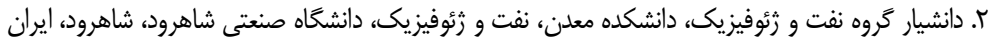

جكيده

كاوش در آثار به جاى مانده از كذشتگًان داراى اهميت ويثهاى در شناسايى تاريخ و هويت يك سرزمين دارد. ييشرفت دانش بشرى

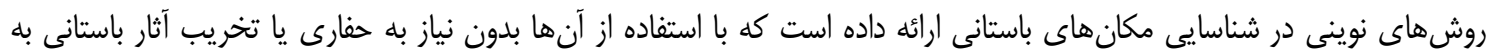

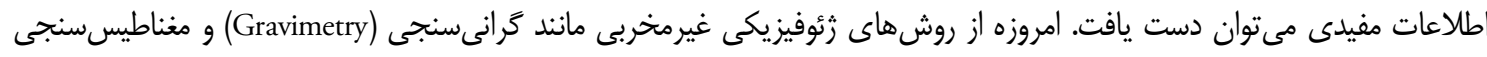

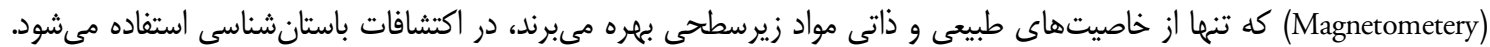

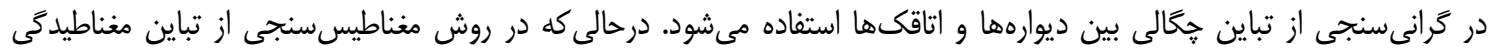
(Magnetization)

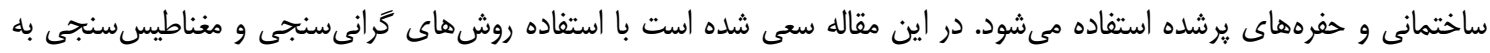

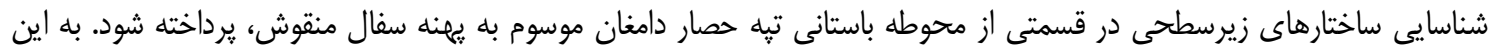

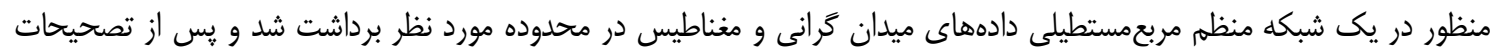

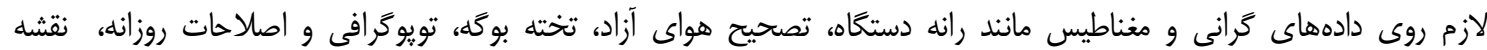

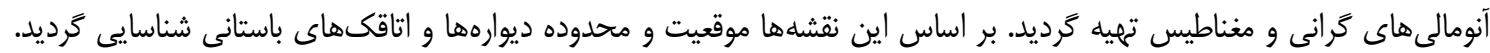

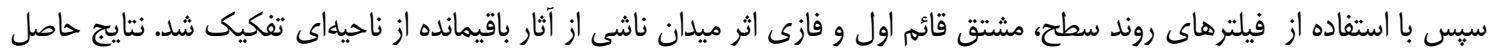

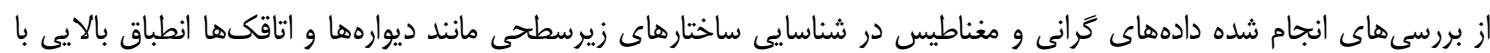

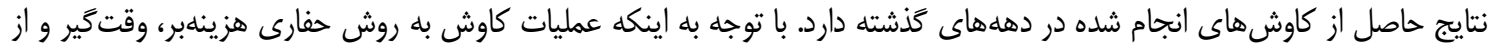

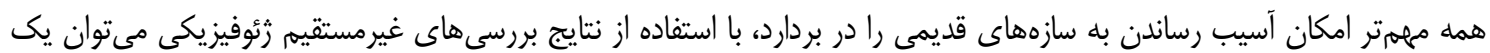
طرح كلى براى كاوشهاى باستانشناسى بلوسيله حفارى طراحى و اجرا نمود تا آثار زيرسطحى كمتر آسيب ديده و حفريات هدفمند

وازههاى كليدى: باستانسنجى، گرانى و مغناطيسسنجى، بارزسازى لبه، فيلترهاى فازى، تيهحصار.

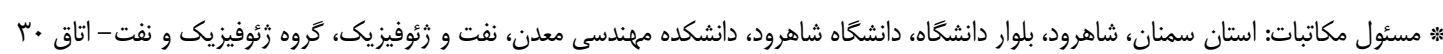

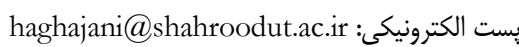
(C) حق نشر متعلق به نويسنده(كان) است و نويسنده تحت مجوز Creative Commons Attribution License به مجله اجازه مى دهد مقاله حاب شده را با ديگران به اشتراك بخذارد منوط بر اينكه حقوق مؤلف اثر حفظ و بونه بهن انتشار اوليه مقاله در اين مجله اشاره شود. 
زيرسطحى مسكونى در بخشى از محوطـهـ باسـتانى تِّهـ

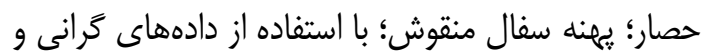

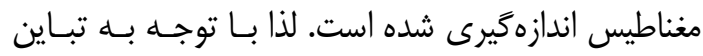

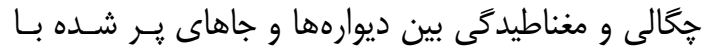

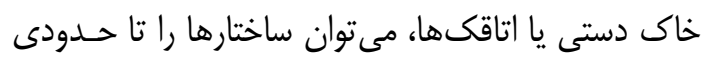

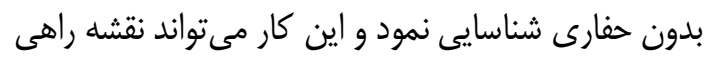
براى حفارى هدفمند در كاوشهاى باستانى باشد.

\section{r. بيشينه استفاده از روش هاى كَرانىسنجى و}

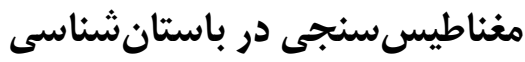

تخمين محل بىهنجارى هاى (Anomaly) منفى (حفرها)

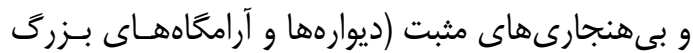

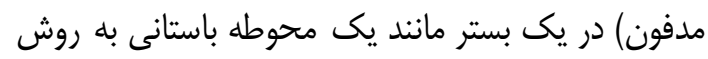

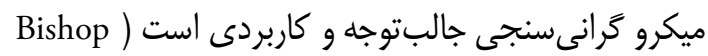
(et al., 1997, p. 156

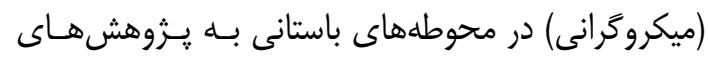

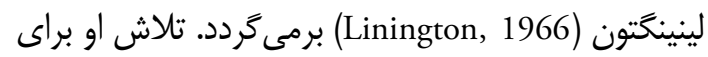

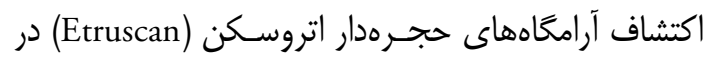
ايتاليا خيلى موفق نبود. البته بعد از آن كارهاى موفقى در اكتشاف سردابها، دهليزها و تونلهاى باستانى صـورت كرفتــه اسـت، امـا

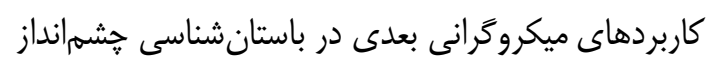
خوبى از اين روش نشـان داد. اسـلياك (Slepak, 1999)

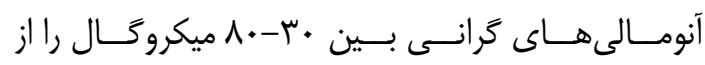

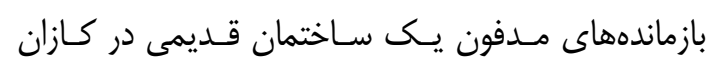

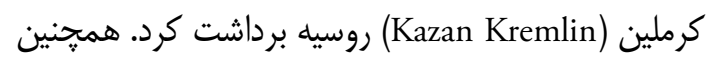
آنومالى هاى ميكروگرانى بالاى باقىماندههاى ديوار ههاى

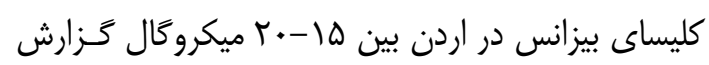
شده است (Batayneh et al., 2007, p .156). پاستـكا و يانيسف (Pánisová \& Pašteka, 2009) با استفاده از روش

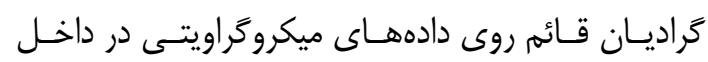

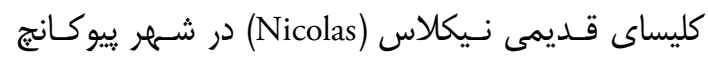

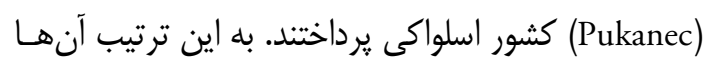

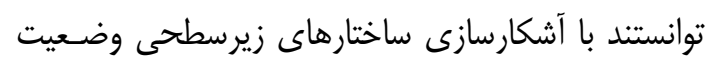
زيرسطح اين بنا را توصيف و حفرهاى در يكى مترى زيــر

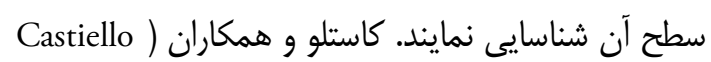

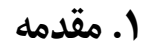

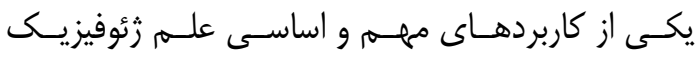
(Geophysics)

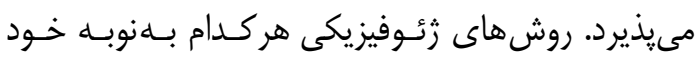

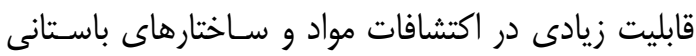

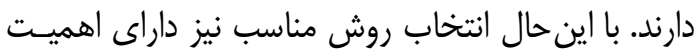

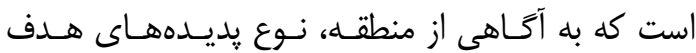

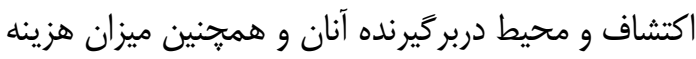

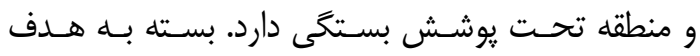

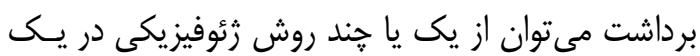

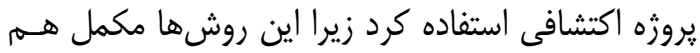

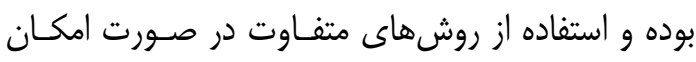
باعث افزايش اطمينان به تفسيرهاى بهدستآمده مى شود

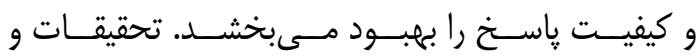

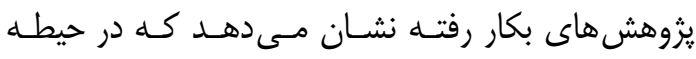

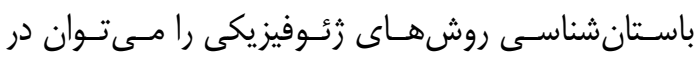
شناسايى و بارزسازى ساختار معمارى مـدفون در خـاك،

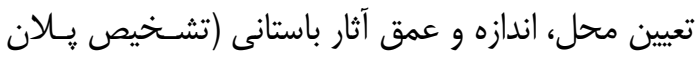

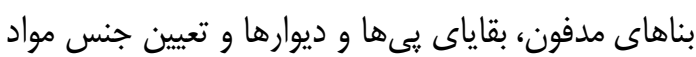

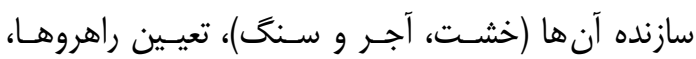

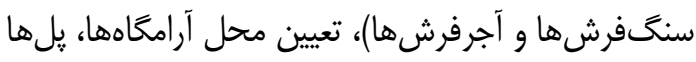

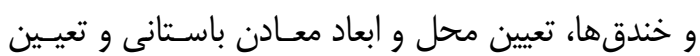

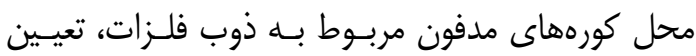

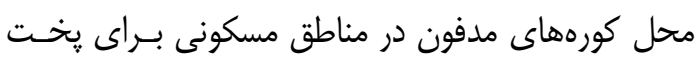

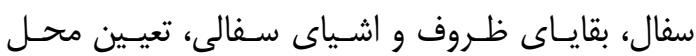
ضخامت خاكهاى سوخته لايههاى خاكستر و خاكهاى دستخورده توسط بشر بكار مىرود ( Alitajer \& Afshari

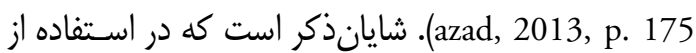

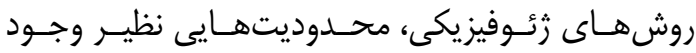

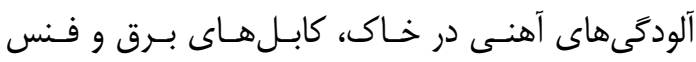
كشى هاى موجود در منطقه، توسعه اراضى كشاورزى، مواد صنعتى، رشد زندگى شهرنشينى و ارتباطات دارد كه سبب

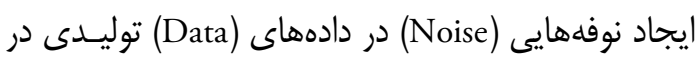
برخى از روشهـاى زئسوفيزيكى مسىشـود ( Alitajer \& (Afshari azad, 2013, p. 175 هدف از ايـن كـار تحقيقى شناسـايى سـاختارهاى 
سابقه استفاده از مغناطيسسنجى در باستانشناسى

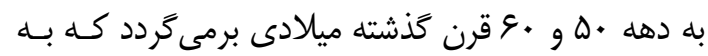

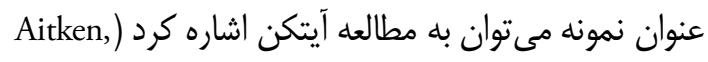

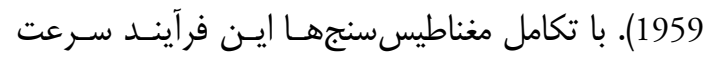
بيشترى يافت، به گونهاى كه مدتزمان كمتـرى كـاوش

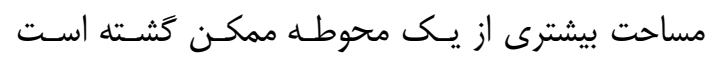

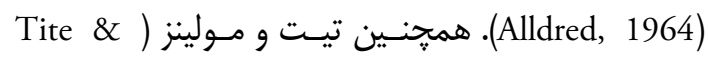

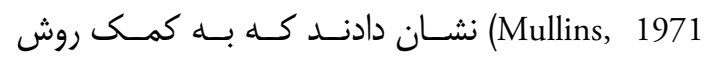
مغناطيسسنجى مى توان آثار قديمى و باستانى معمـارى

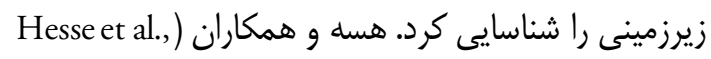
1997) از روشهاى مغناطيسى و مقاومت ويثه الكتريكى با قدرت تفكيك مكانى زياد براى بررسى سايت باسـتانى

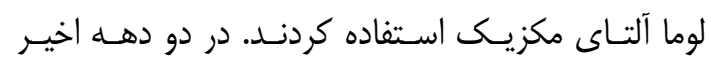
بلهواسطه تكامل فيلترها، روشهـاى يردازشـى و امكـان

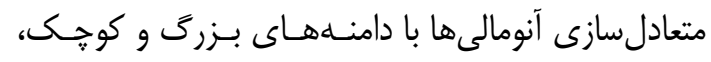

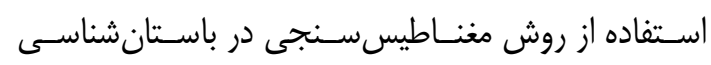

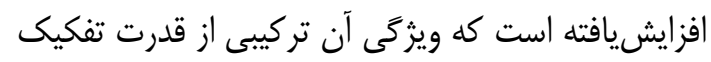

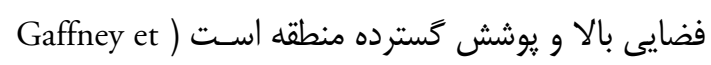

در ايران نيز از سال سهسا تاكنون محوطههاى بسيار

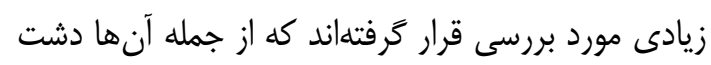

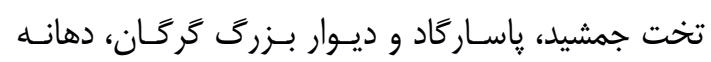

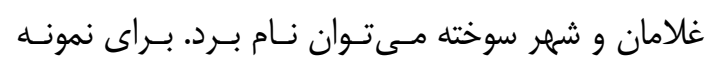

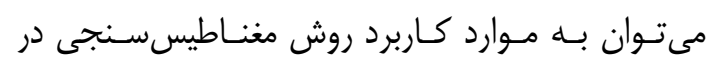

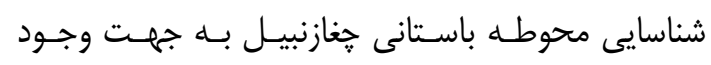
خاصيت مغناطيسى باقى مانده حرارتى در بقاياى سازههاى جناي

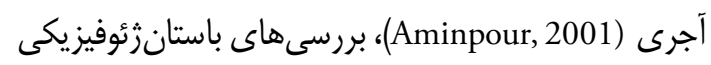

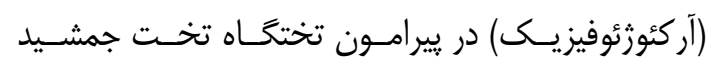
(Mohammadkhani, 2004)

\section{". معرفى منطقــه و دسـتخَاههـا و روشهــاى استفاده شده}

محوطه باستانى تِـهـ حصـار (Teppe-Hissar) در جنـوب شرقى شهر دامغــان (Damghan) در اسـتان سـمنان بـا

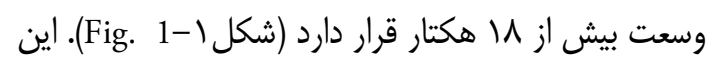

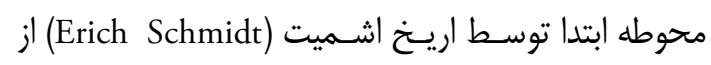

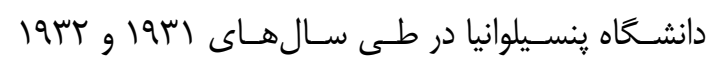

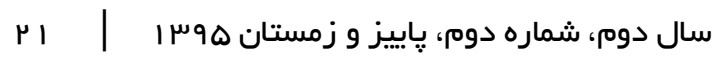

نيز حفرههاى زيرسـطحى در محـيطهـاى (et al., 2010 شهرى نايل (Napoli) را به روش گرانى بررسى كردند. در

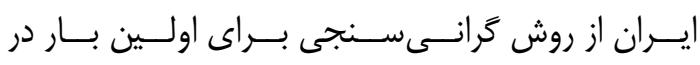
باستان شناسى استفاده مىشود. در مقدار گرانى مشاهدهاى

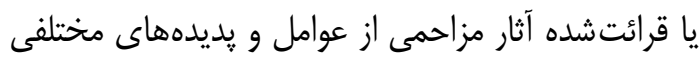

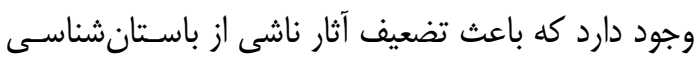

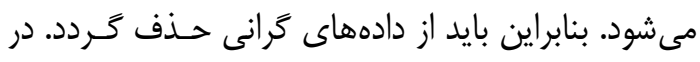

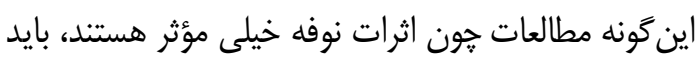

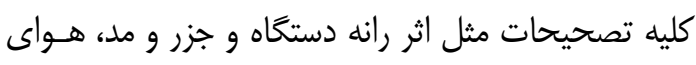
آزاد، تخته بوگه و تويوگرافى با دقت بالاترى انجام شوند. نتايج حاصل از بررسىهاى صحرايى

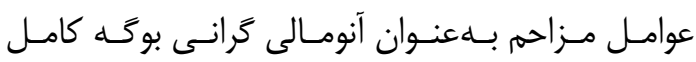
خوانسده مسى شـود؛ كـه داراى دو لو (Complete Bouguer) مؤلفه ناحيهاى (Regional) مربوط به ساختارهاى عميق و

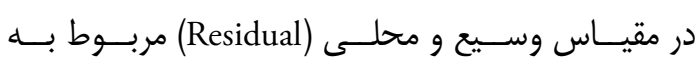

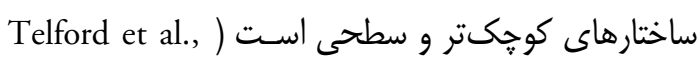
.(1990, p. 11-13 مطالعه مغناطيس زمين قديمىترين شاخه زئوفيزيك

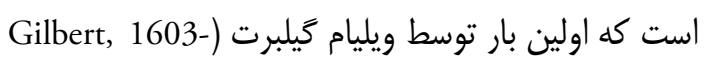

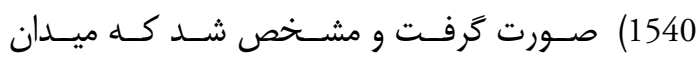
مغناطيسى زمين همارز يك مغناطيس ماندًار (آهـنربـا)

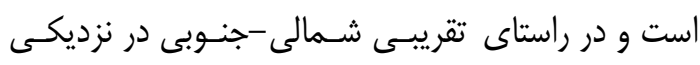

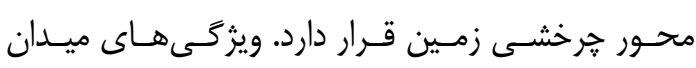

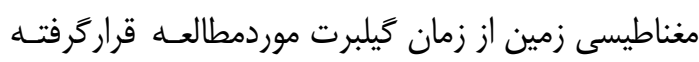
بود اما در سال سعما فنورده (Von Wrede) براى اولين بار تغييـرات ميـدان را بـراى تعيـين محـل كانسـارهاى

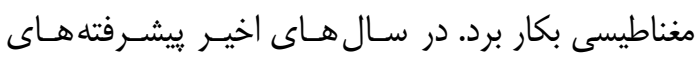
قابل توجهى درزمينهى ساخت دستخاهها و تفسير دادههاى بـى برى

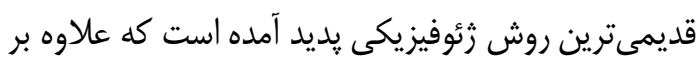

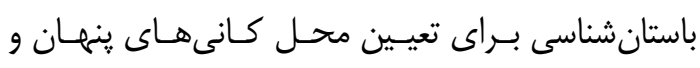

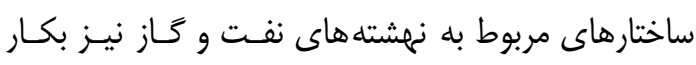

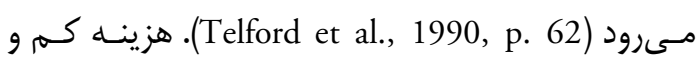
سرعت بالا در مقايسه با ديخر روشهاى ثئوفيزيكى باعث شده است تا اين روش بلخصوص در يروزههاى در سطح وسيع استفاده شود. مغناطيدگى ناشى از يك خاصيت ذاتى

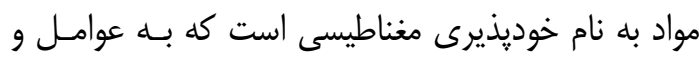
شرايط مختلفى بستخى دارد. 


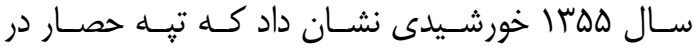

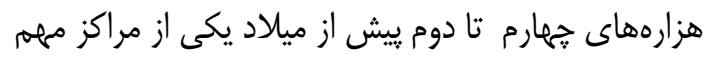

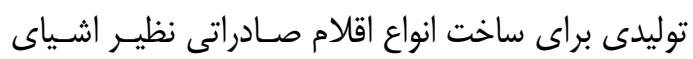

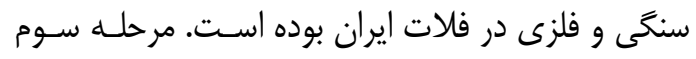

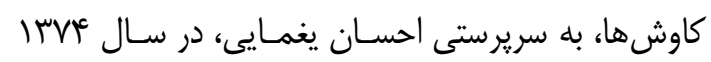

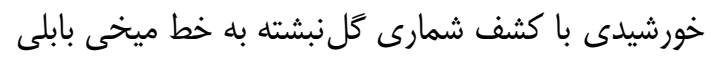

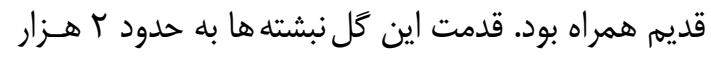

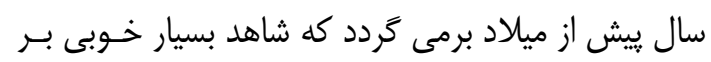

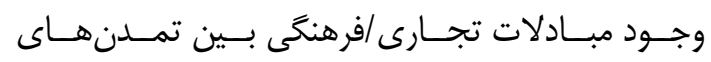

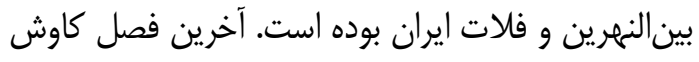

ميلادى مورد كاوشهـاى باسـتانشناسـى قـرار كرفـت

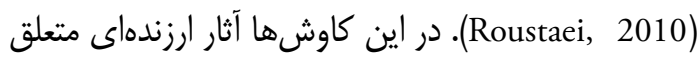

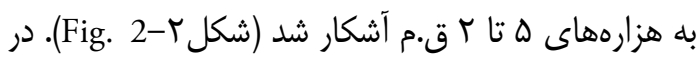

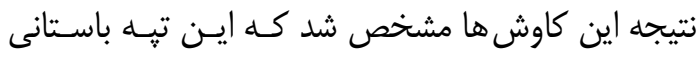

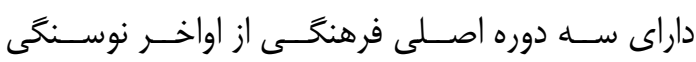

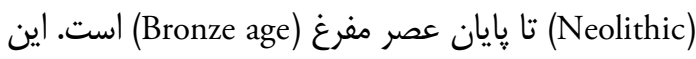
محوطه پِ از اين كاوش بهعنوان يكى از محوطه هـاى

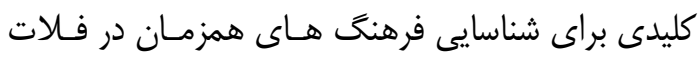
مركزى ايران مورد استناد باستان شناسان قراركر فتنه است. بررسىهاى صورت گرفته در مرحله دوم باستان شناسى در

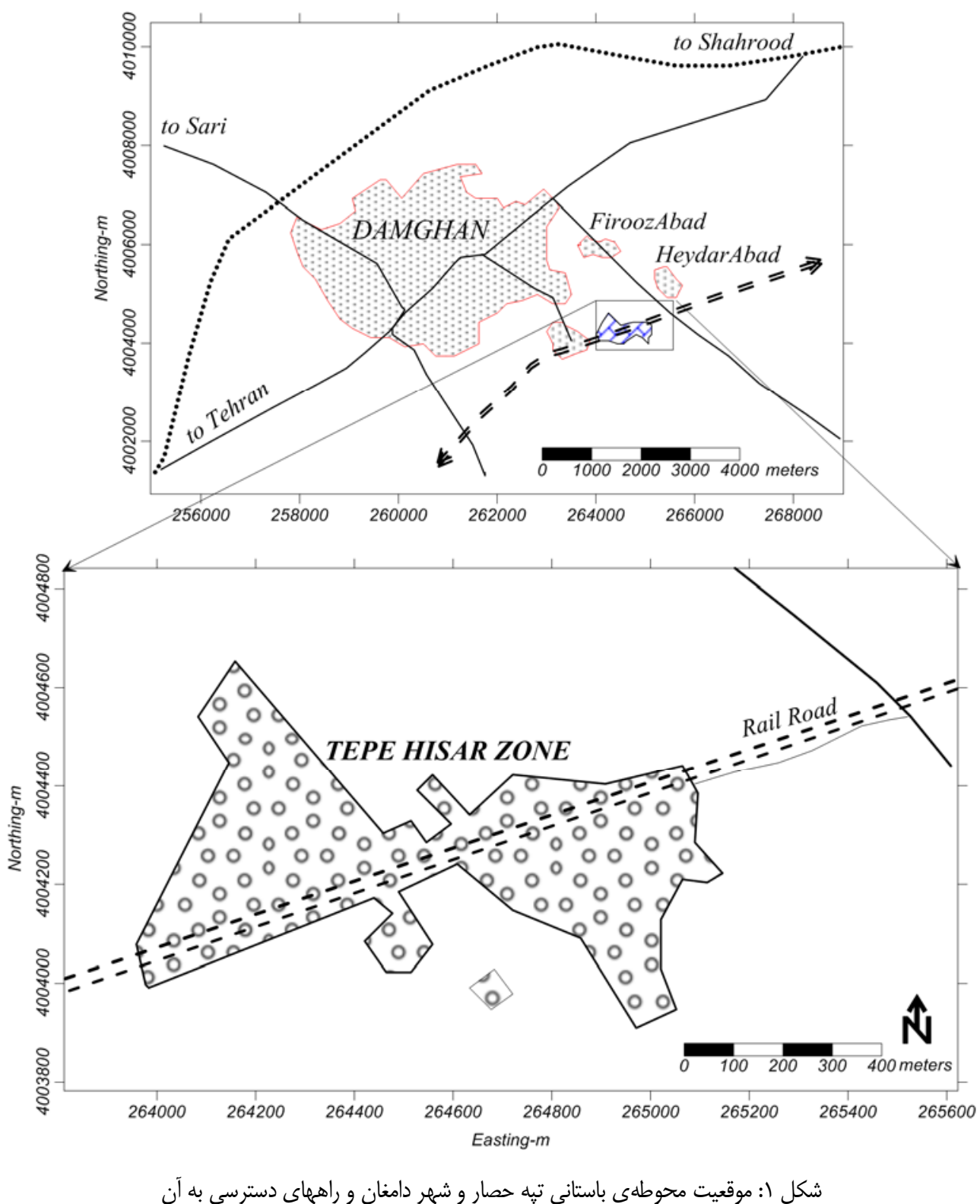

Fig. 1: Location of archaeological site of Tepe Hissar in Damghan and the access road 
دو فصلنامه يزّوهمى باستانسنجى

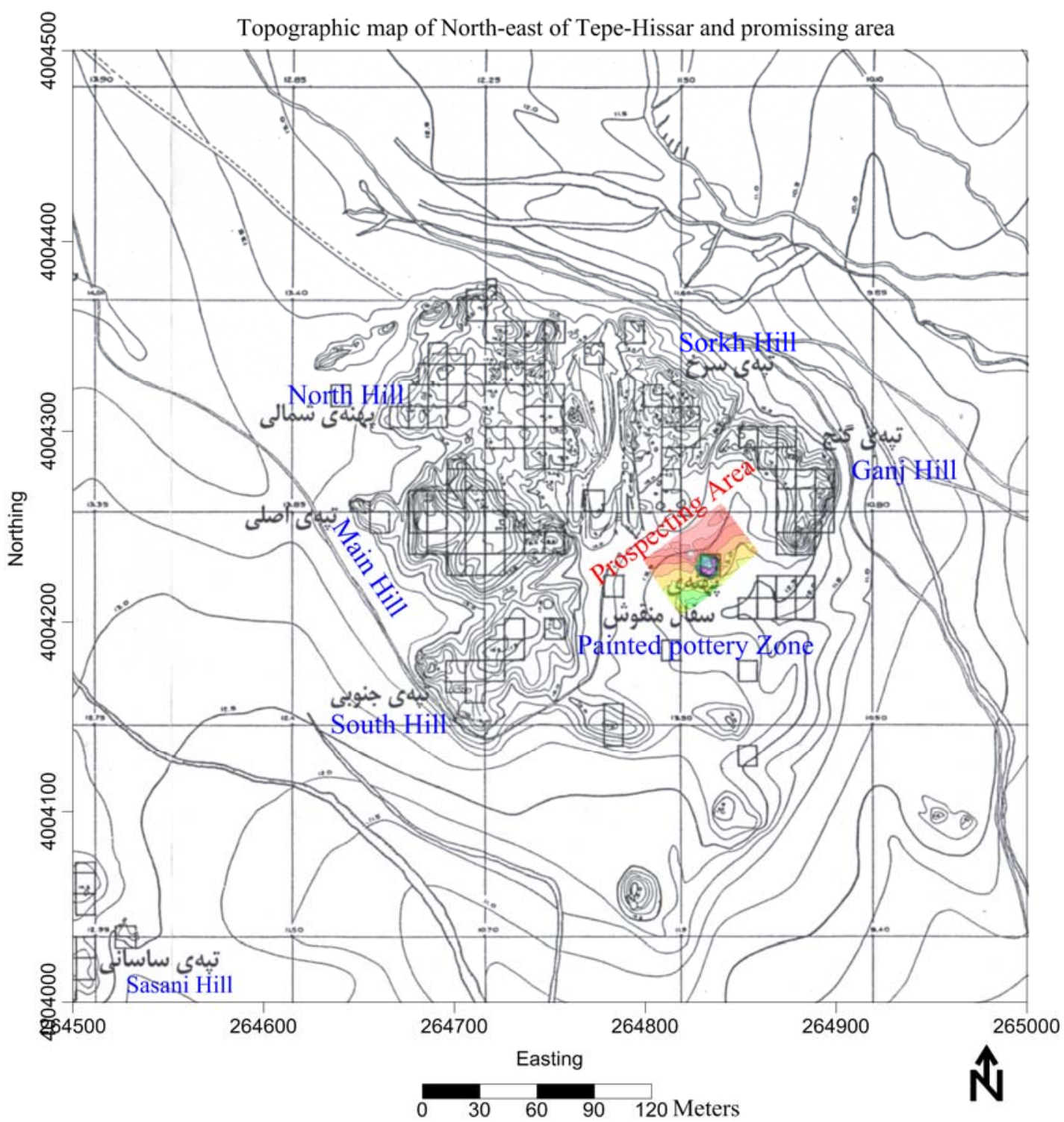

شكل ז: نقشه تويوگرافى محوطه تֶه حصار دامغان، محدودههاى كاوش شده بلهورت مربعهاى كوجى ديده مى

Fig. 2: Tepe Hissar (Damghan) topographic map and gravity surveying area, the main areas of excavated are shown in squares (After Schmidt, 1937; Roustaei, 2010 p. 53).

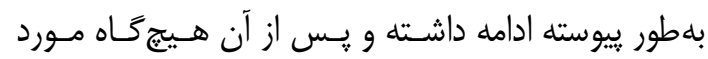

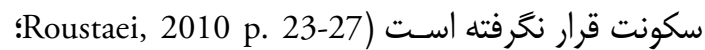
تابلوى ورودى تيه حصار). در اين محوطه باستانى جندين

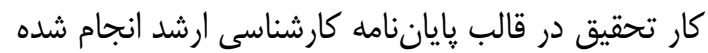
است. همجنــين در كـار يثزوهشـى احمـديور و همكـاران جهـت بررسـى وضـعيت (Ahmadpour et al., 2017) ساختارهاى زيرسطحى در محدوده از مدلسازى مستقيم و و معكوس دادههاى رادار نفوذى به زمين استفاده كردند.

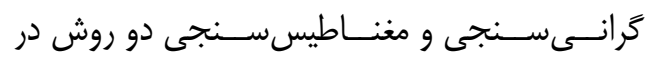

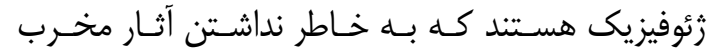

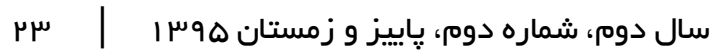

در تيه حصار توسط هيئتى باستانشناسى بــه سريرسـتى

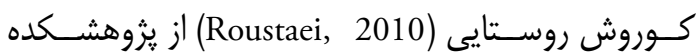

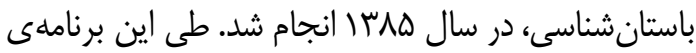
ميدانى كه بلمنظور تعيين عرصهى واقعى محوطه انجـام

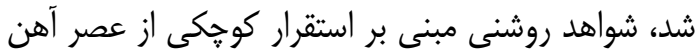

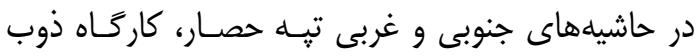
كانسنَ مس و گورستانى از همين دوره آشكار شد.

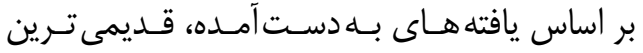
لايه هاى تِه حصار به اواخر هزاره پــنجم قبـل از مـيلاد

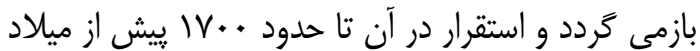


مىتواند محل آرامخاههاى مدفون و يا يـى ديـوارههـاى

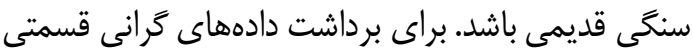

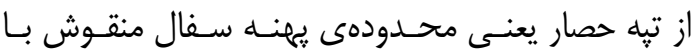

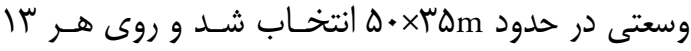
يروفيل (Profile) با فاصله m اد دادها برداشت شد. فاصله

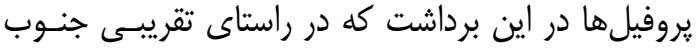

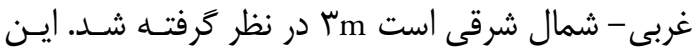
فاصله شبكهبندى با توجه به ابعاد ديوارهها و اتاقكهايى استى

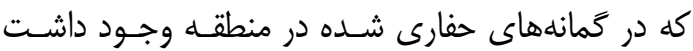
انتخاب شده است. در كل شبكهاى با بيش از •و عه نقطه

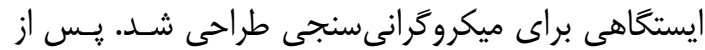

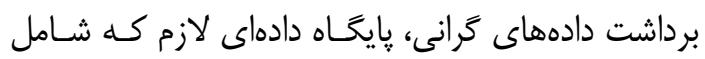
مختصات نقاط برداشت، ارتفاع نقاط، مقدار كرانى و زمان برداشت دادهها تنظيم و در يك فايل دادهاى در نرمافزرار

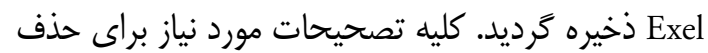

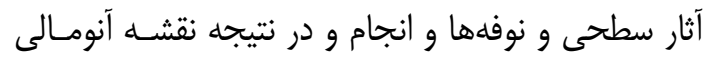

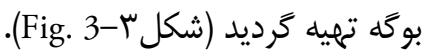
همان كونه كه ذكر شد، اين نقشه شـامل اطلاعـات

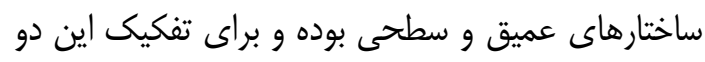
از هم و شناسايى آنومالى كه ناشى از ديوارهها و اتاقكها

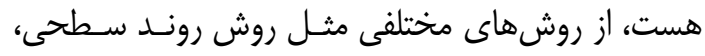

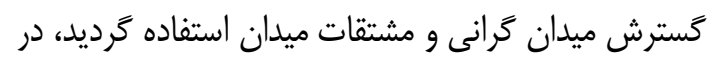

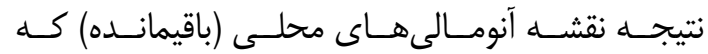

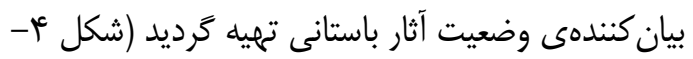

.Fig. 4

با توجه به اينكسه در محسدوده باستانى تِّهـ حصـار

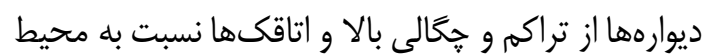
اطراف بهوسيلهى موادى با جحالى كمتر ير شده است، لذا

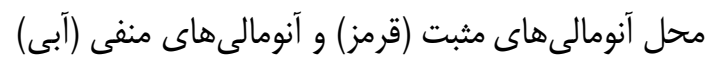
مىتواند مشخص كننده اين يديدهها باشد. بر اساس ايسن

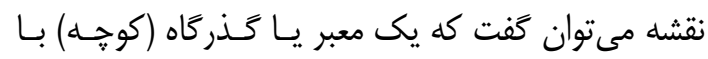

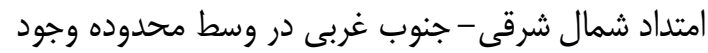

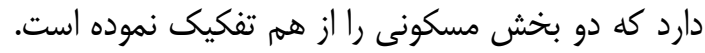

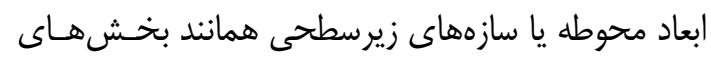

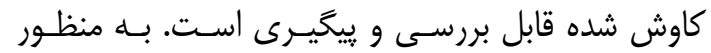

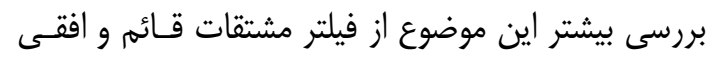
بلهصورت همزمان در قالب فيلتـر زاويـهـ تمايـل استفاده

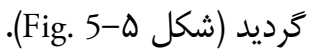

محيطى مىتوانند در باستانشناسـى كاربردهـاى زيـادى

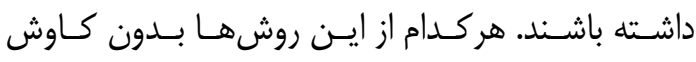

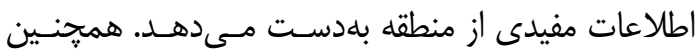

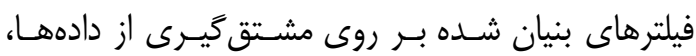

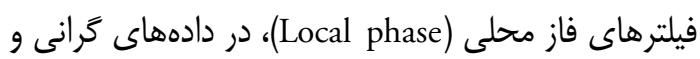

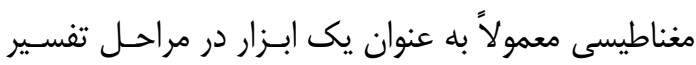

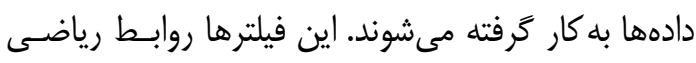
هستند كه با تركيب مشتق دادهها در راستاى محورهـاى مختصات لبههاى آنومالىها را بارزتر كرده و تفسير دادهها

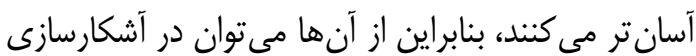
لبهها و تعيين مرز ساختارى استفاده نمود كه اينجا از فيلتر

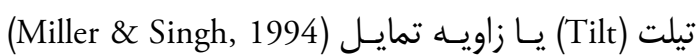

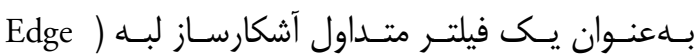
detection

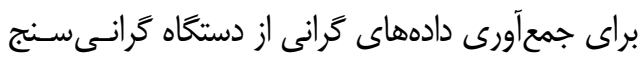

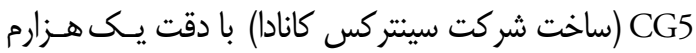

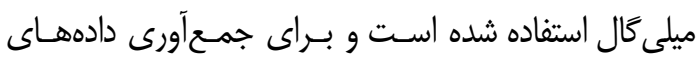
مغناطيس سنجى از دستخاه مكتتومتر بروتون ساخت شـركت رئوماتريكس با دقت يك نانوتسلا استفاده شده است.

\section{f ا. دادهاى كرانى سنجى و بحث درباره نتايج آن}

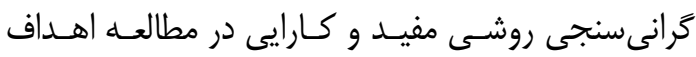
اكتشافى مىباشند. روش كرانى سنجى بر مبناى اختلاف

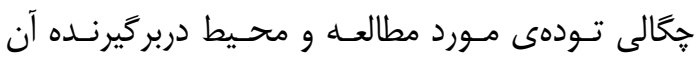

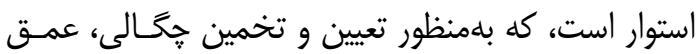

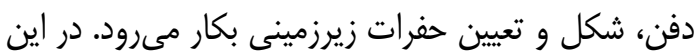

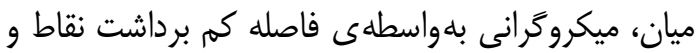

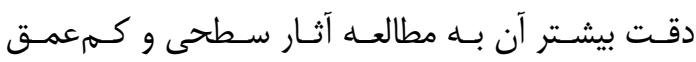

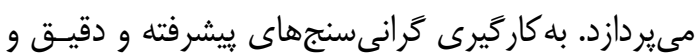
ايجاد روشهاى يردازشى و تفسيرى جديد براى دادههاى

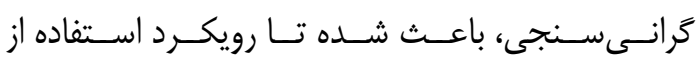

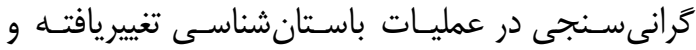
افزايش جشمخيرى در دنيا بيدا كند. در اين شاخه با توجيه

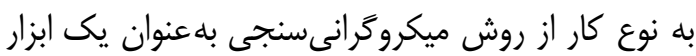

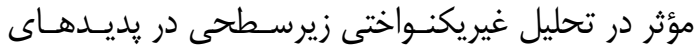
مختلف استفاده مى تشود.

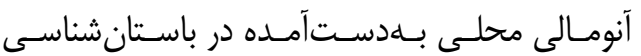

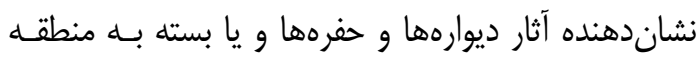

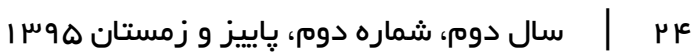




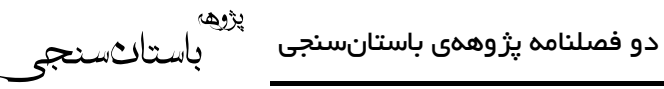

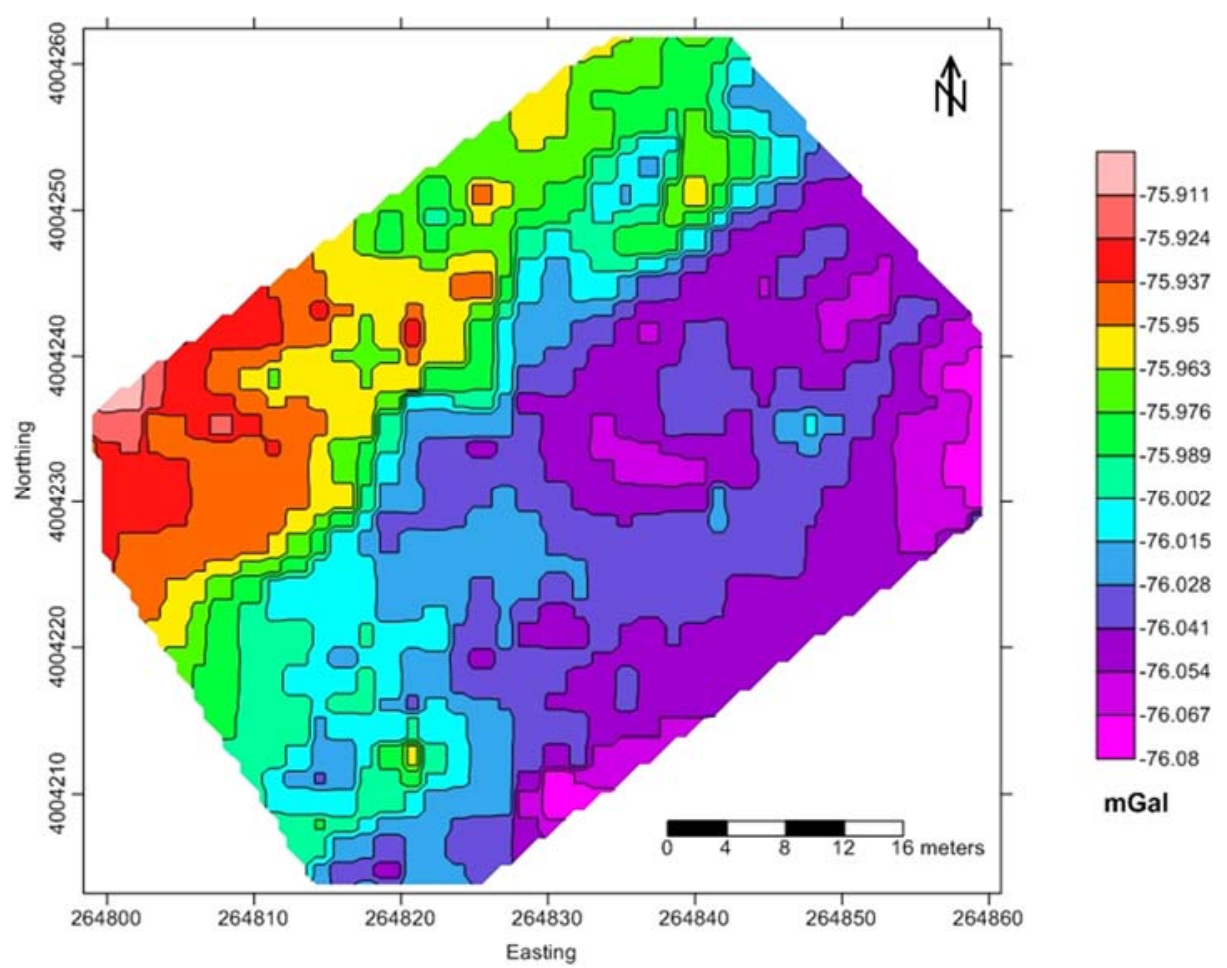

شكل "ا: بى هنجارى گرانى بوگَه محدوده مورد مطالعه

Fig. 3: Bouguer gravity anomalies on the study area

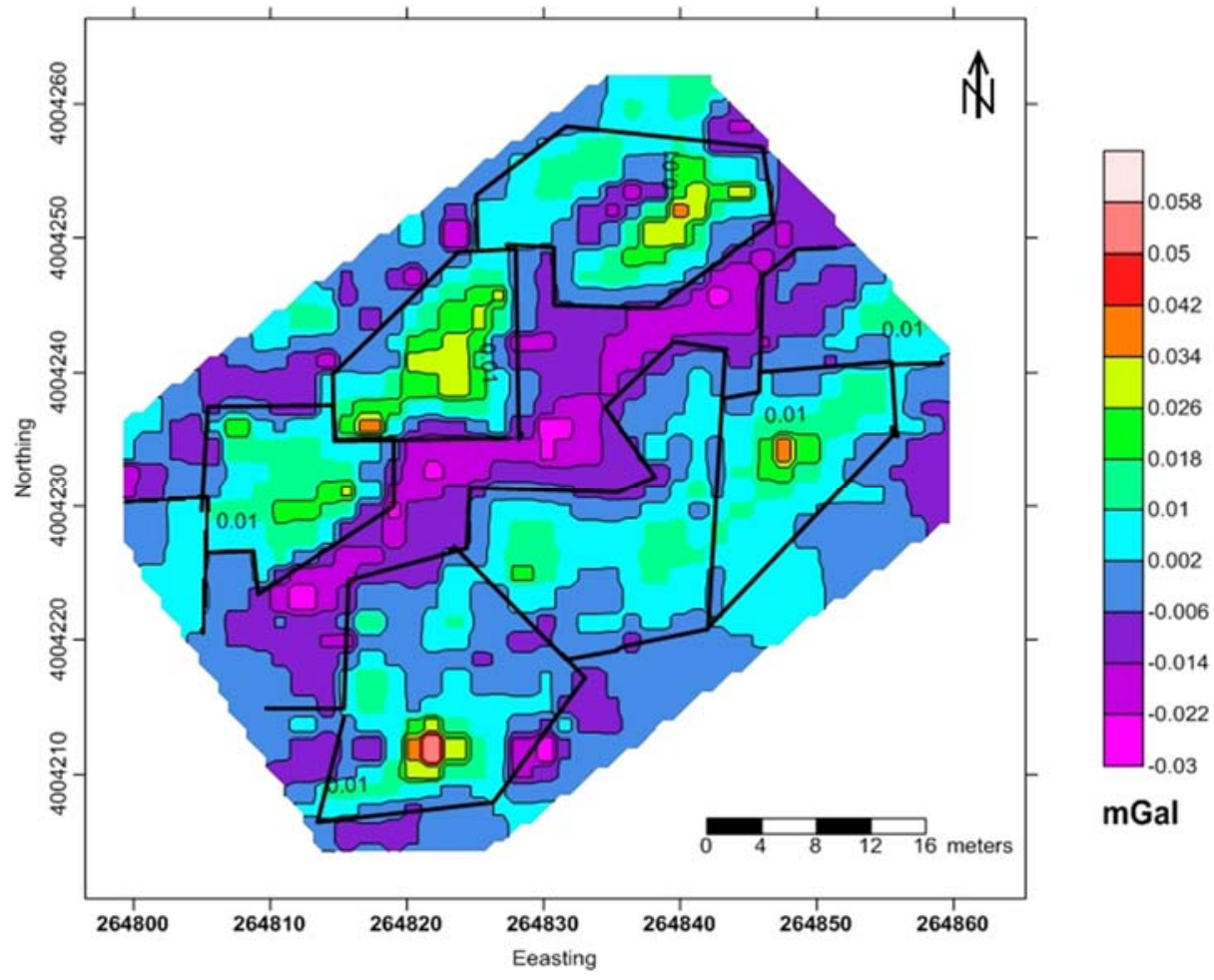

شكل عا: بىهنجارى گرانى باقيمانده از روند سطح مرتبه هفت محدوده مورد مطالعه

Fig. 4: Residual gravity anomaly from $7^{\text {th }}$ order trend surface method on the study area

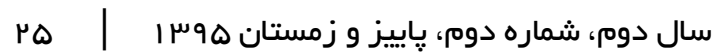




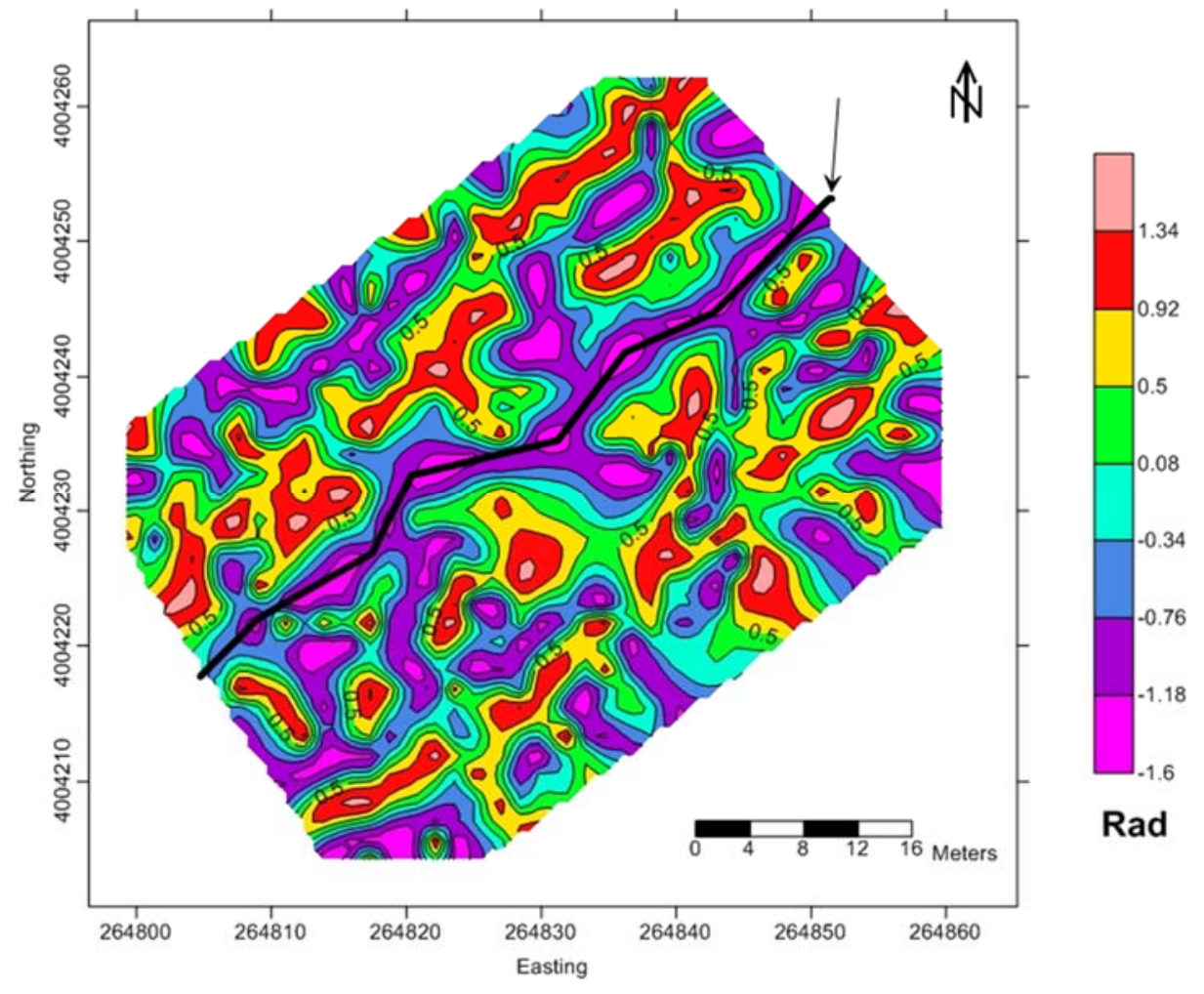

شكل ه: نقشه اعمال فيلتر زاويه تمايل روى بىهنجارى گرانى محدوده مورد مطالعه

Fig. 5: Tilt angle map of gravity data covering study area, Tepe Hissar

\section{ه. دادههاى مغناطيسسنجى و بحـث دربــاره}

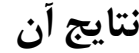

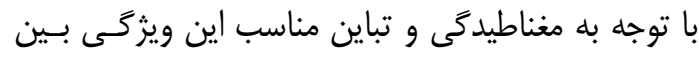
ساختارهاى زيرسطحى در محوطههـاى باستانى از ايـن روش مىتوان در شناسايى مناطق باستانى استفاده كـرد. مغناطيدگى مى تواند در مواد باستانى مثل كورهها، تنورها،

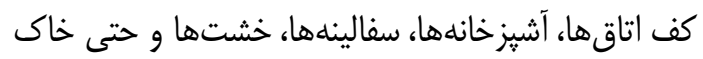

$$
\text { هوازده ايجاد شود. }
$$

بلهور كلى نتايج بررسىهاى مغناطيسى در منـاطق باستانى به دليل تغيير مغناطيدكى در محـيط اولاً در اثر

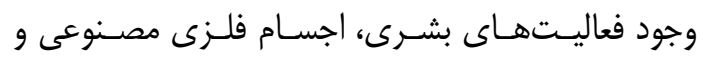

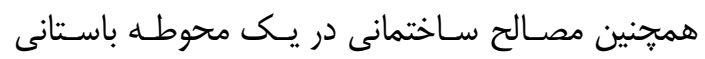

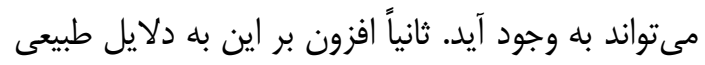

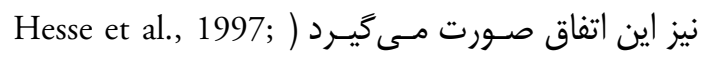

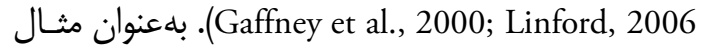
به خاطر افزايش تركيبات آهندار، به ويزه اثـرات اكسـيد

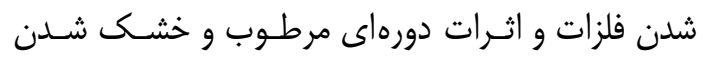

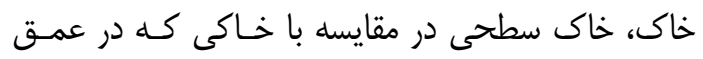

مطابق اين شكل آثار ديوارهها و اتاقكها با وضـوح بهترى به تصوير كشيده شده است. با توجه به اينكه مرز

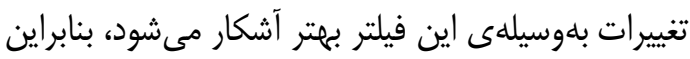
از اين روش براى تفكيك ساختارهاى زيرسطحى استفاده

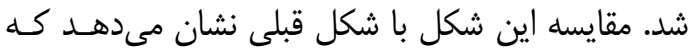

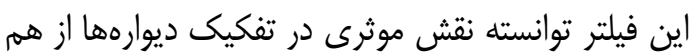

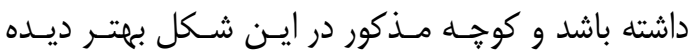

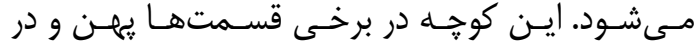

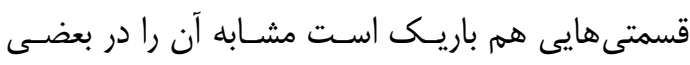

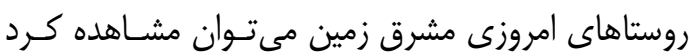

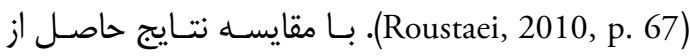
عمليات ترانىسنجى (بدون تخريب و حفارى) بـا نتـايج

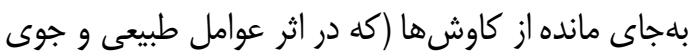
تا حدود زيادى تخريب شده و ديوارهها از بين رفتـهانـــا

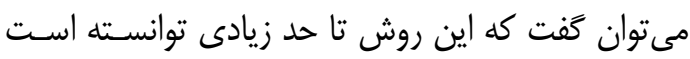

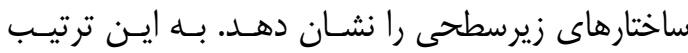

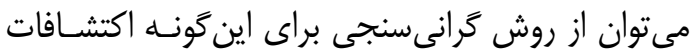

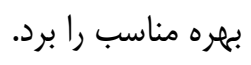

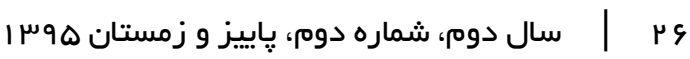


آنومالى هاى مغناطيسى اندازهگيرى شده در سـطح،

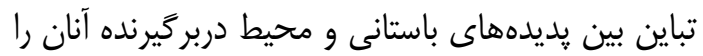

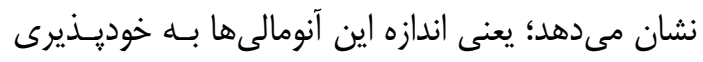
مغناطيسى هر دو عامـل بسـتخى دارد. در محيطى كـهـ

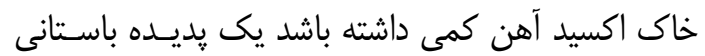
مثلاً يكى ديوار خشتى تا حدودى قابل شناسـايى اســـ امـا

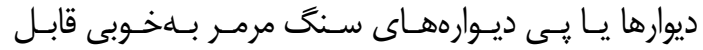
شناسايى نيست. در مورد خاك با اكسـيد آهـن زيـاد تبـاين خوديذيرى مغناطيسى بين جسم آنومـال و محـيط معمـولاً

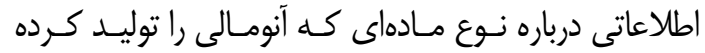

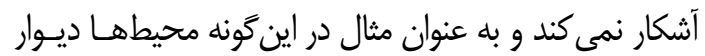

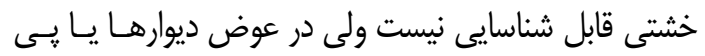
ديوارههاى سنَ مرمر بهخوبى قابل شناسايى است. در دادههــاى مغناطيسـى تبــاين مثبـت عمومــاً در

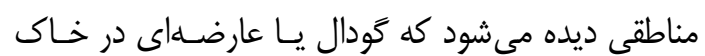

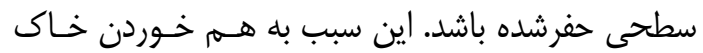

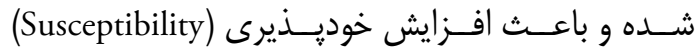

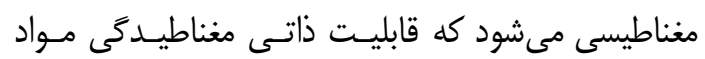
است (Linford, 2006, p. 2224). آنومالى هاى منفى نيز

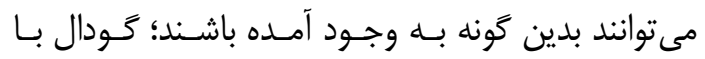

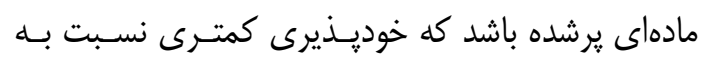

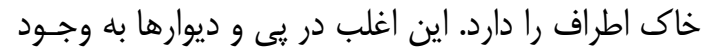

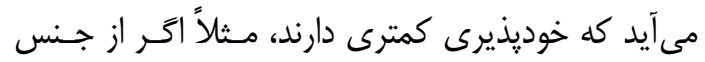

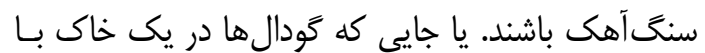
مغناطيدگى بالا حفرشده باشند و با موادى با خوديـذيرى گيائين يرشده باشند.
بيشتر قرار مى گيرد مغناطيدگى بيشترى دارد، لذا جابجايى خاك موجود در گورها و اتاقكهاى يكى محوطه باستانى

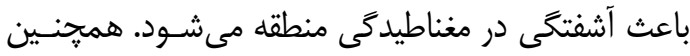

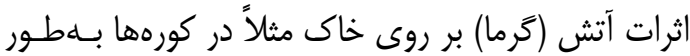
خشم گيرى باعث افزايش مغناطيدگى مى شود. هنخامى كه

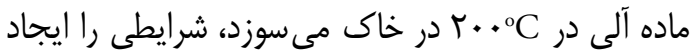
مى كند كه سبب تبديل هماتيت بـه مخَتيـت مسى شـود.

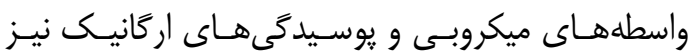

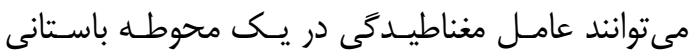
باشند. در اين شيوه باكترى شـرايط تبـديل را بــه وجـود

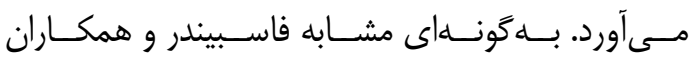

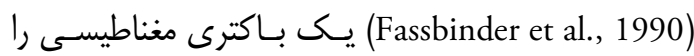
كشف كردند كه نوع خاصى از باكترى است كه بلورهاى

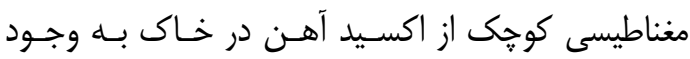

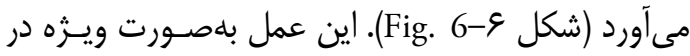
Clark, 2003, p. 99-101) يوسيدن جوب صورت مى گيرد .(Aspinall et al., 2008, p. 23-26 ; براى خشتهاى رسى كه معمـولاً يـس از حـرارت .

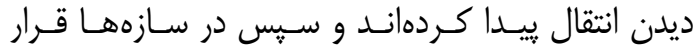
دادهشداند، آرايش حوزههاى مغناطيسى خشتها يسا در كنار هم بعد از جابجايى اغلب متفاوت است يعنى ممكن است است ارته

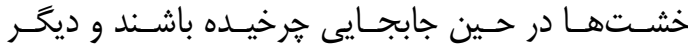

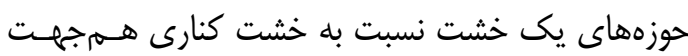

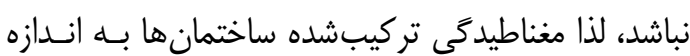

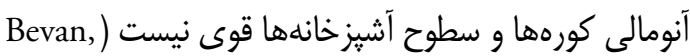
.(1994, p. 96-98; Hessa et al., 1997, p. 63
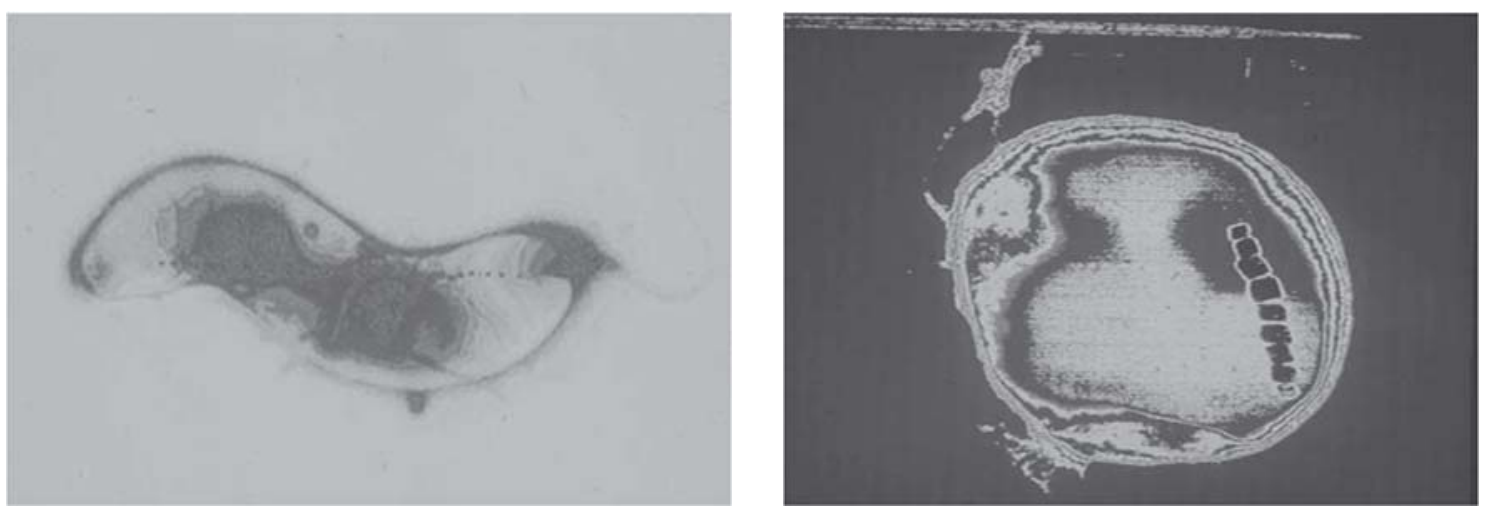

شكل \&: توليد بلورهاى ريزساختار مغناطيسى به وسيله باكترى مغناطيسى

Fig. 6: Magnetic Microstructure crystals which is built by means of Magnetotactic Bacteria (Fassbinder et al, 1990 p.162) 
برداشت شدهى ناشـى از آن) حالـت دوقطبـى دارد، لــذا

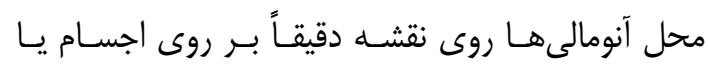

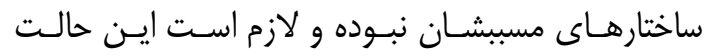

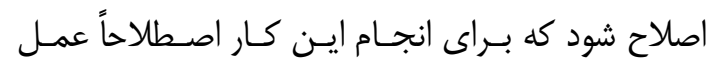
تبديل به قطب (Reduce to magnetic pole يا بـه اختصـار

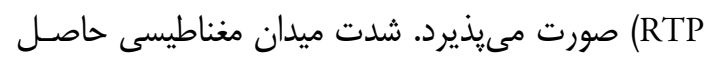

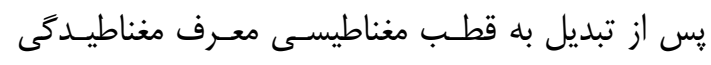

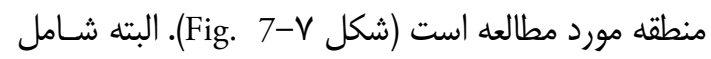

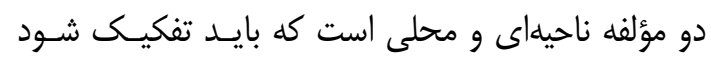

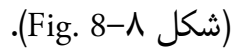

همجنين همانند روش گَرانى سنجى از فيلتـر فـازى

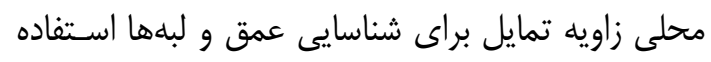

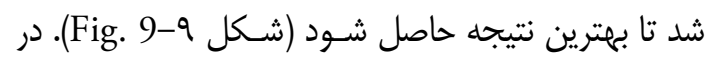

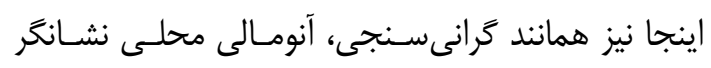

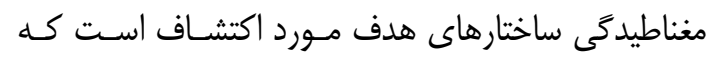
بسته به نوع منطقه متفاوت است.
دادههاى مغناطيسى نيز در يك شـبكهى مـنظهم در

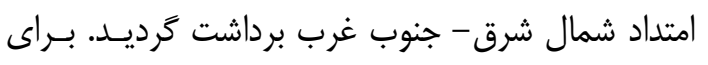

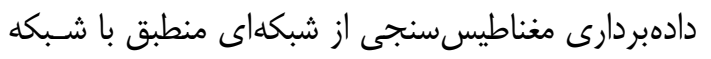

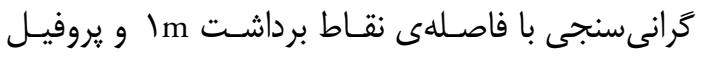

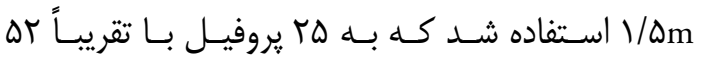

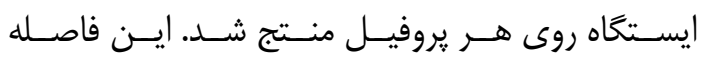
شبكهبندى با توجه به ابعاد ديوارهها و اتاقكهايى كـه درو درد

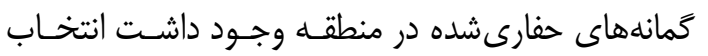

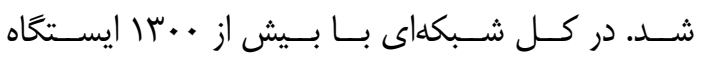

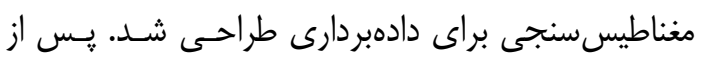

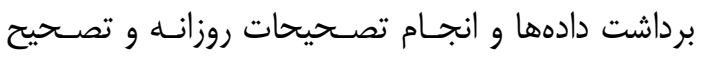
كه (International Geomagnetic Reference Field) IGRF اثر كلى ميدان مغناطيسى زمين را شامل مىشود آنومالى

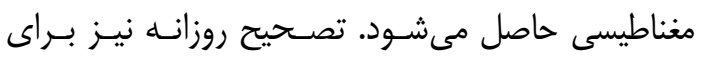

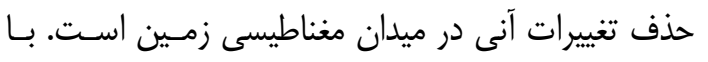

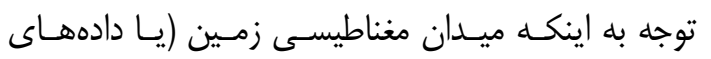

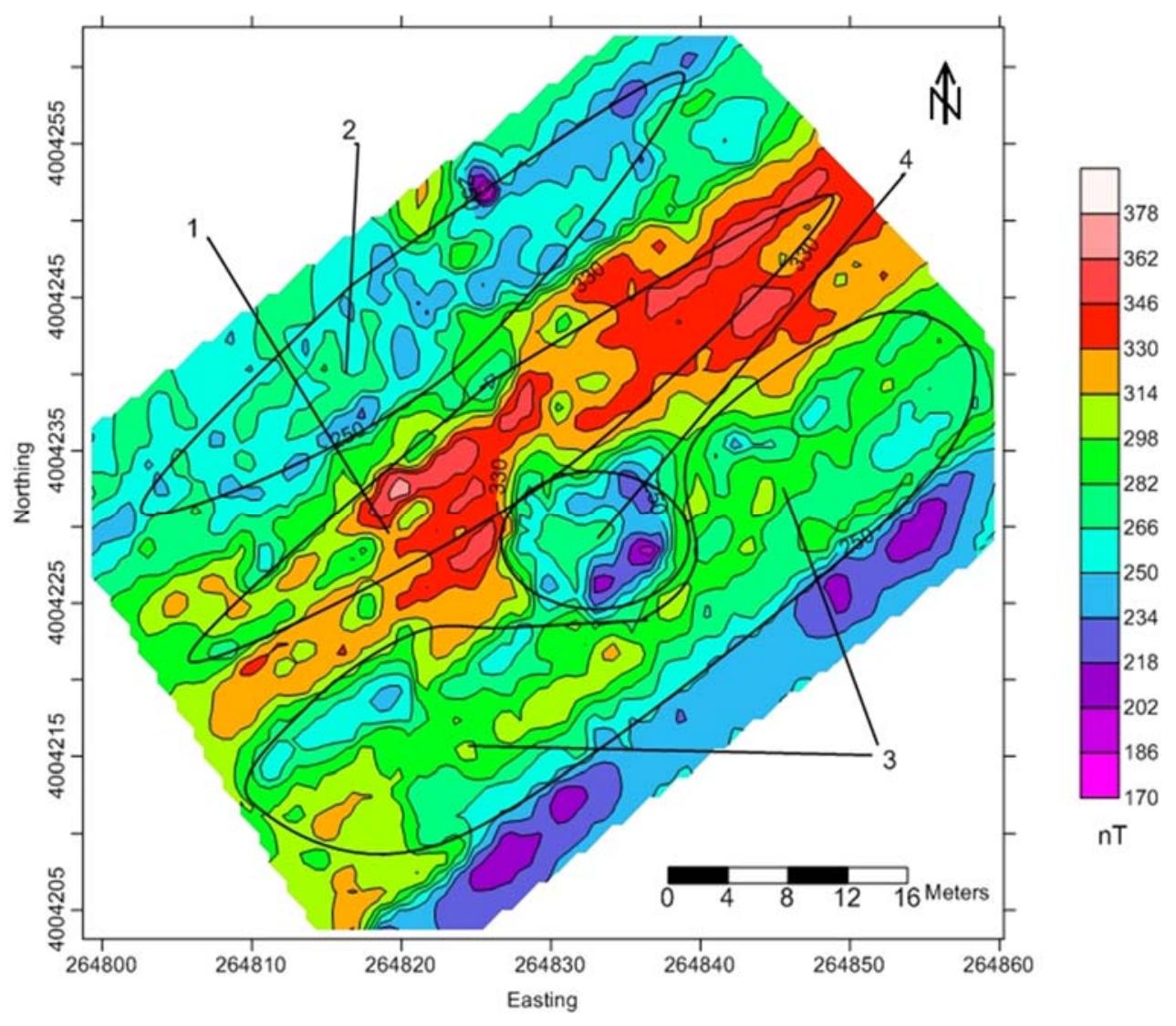

شكل V: بى هنجارى مغناطيسى تبديل به قطب شده محدوده مورد مطالعه

Fig. 7: Reduction to pole of magnetic anomalies on the study area 


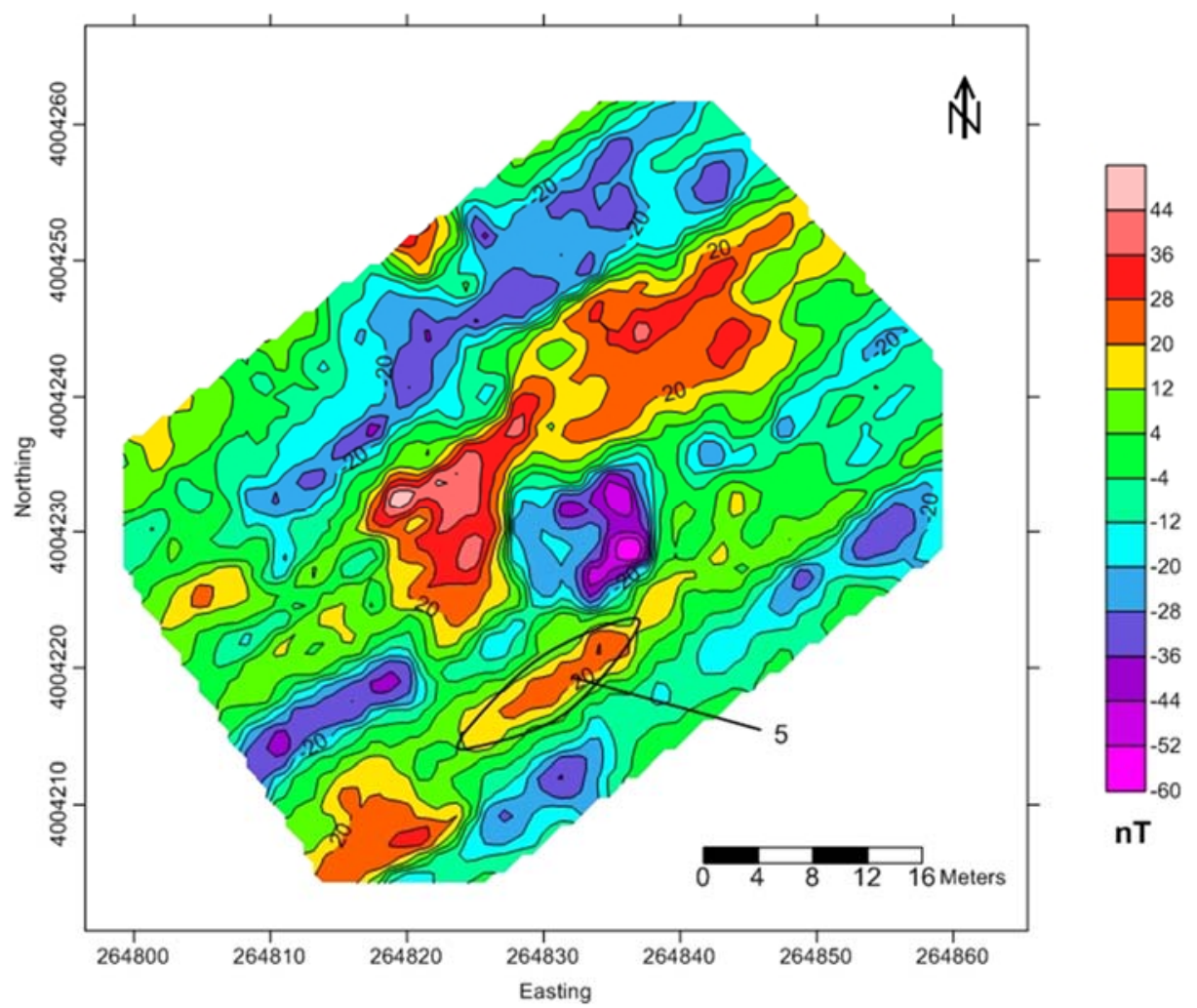

شكل ^: بى هنجارى مغناطيسى باقيمانده از روند سطح مرتبه شش محدوده مورد مطالعه

Fig. 8: Residual magnetic anomaly from $6^{\text {th }}$ order trend surface method on the study area
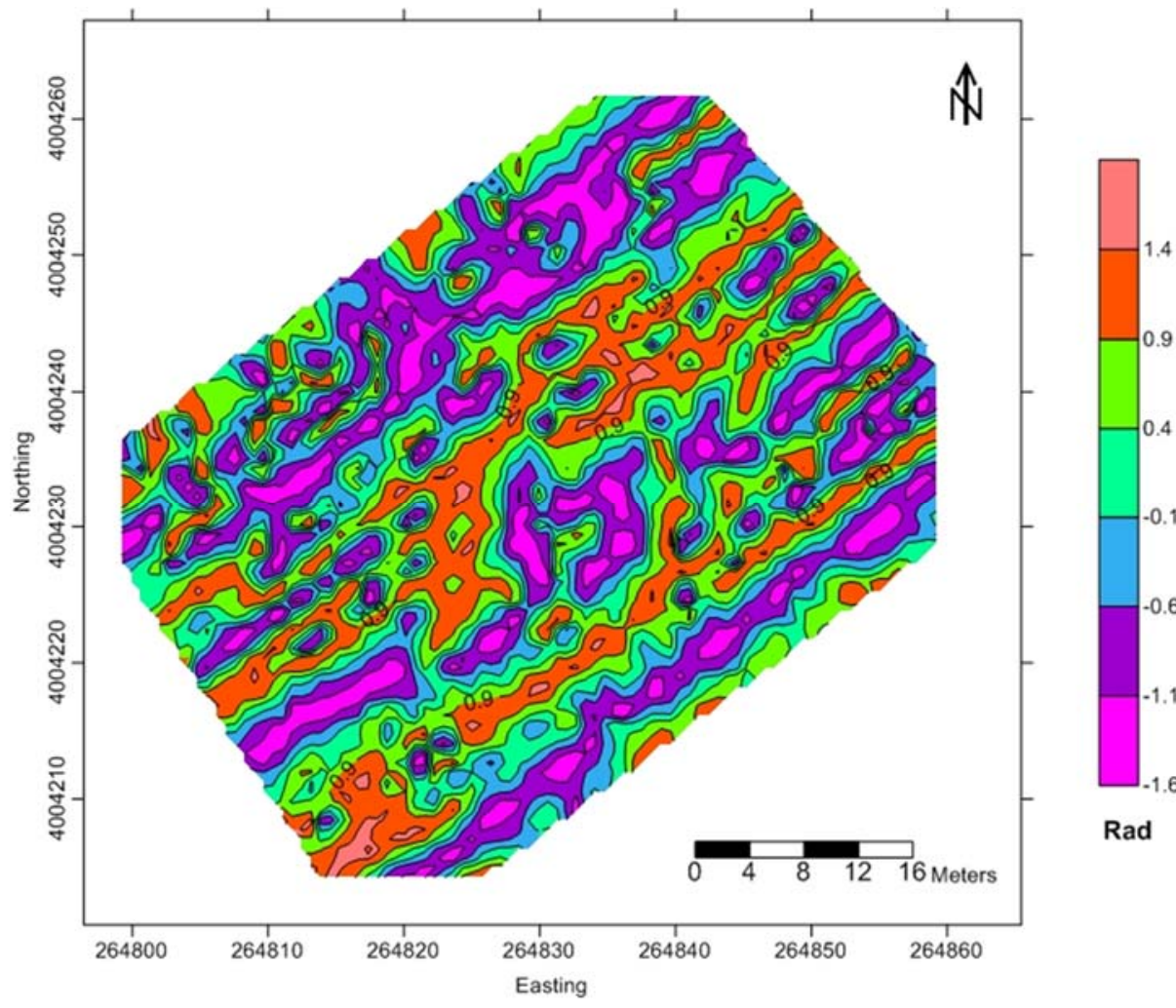

Rad

شكل 9: نقشه اعمال فيلتر زاويه تمايل روى بى هنجارى مغناطيسى محدوده مورد مطالعه

Fig. 9: Tilt angle map of magnetic data covering study area, Tepe Hissar

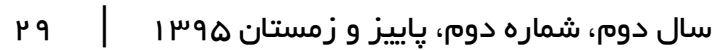


سطحى بودن كه در اين نقشه متمـايز شـــه اسـت ايـن

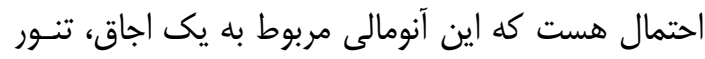

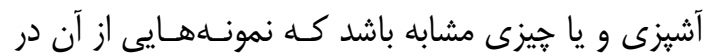
كاوشهاى منطقه يبيدا شده است. در مورد لبههاى نقشـهـ

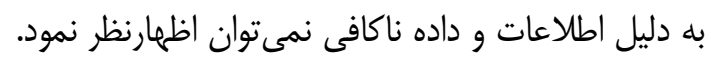

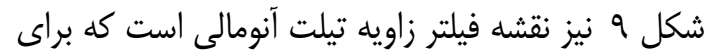
شناسايى لبهها مؤثرتر است و مؤيد نقشههاى قبلى است.

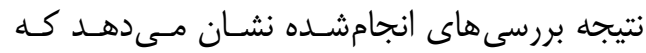
اطلاعات بهدست آمده از كرانى سنجى و مغناطيس سنجى

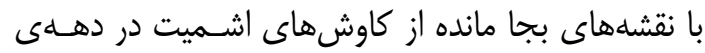

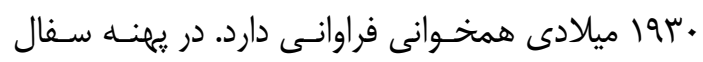
منقوش و قسمت جنوب غربى محوطه برداشـت، تقريبـاً

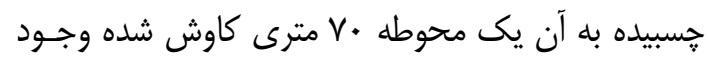

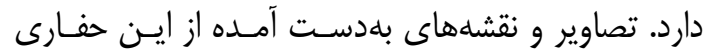
نشان از وجود اتاقكهاى تودرتو و نـامنظه، راهروهـاى

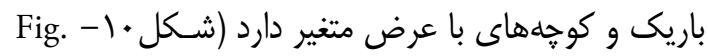
10). اين خصوصيات مربوط به لايههاى سطحى در تبـه

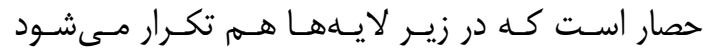
(Roustaei, 2010, p. 62-72). فاصله محدوده كاوش شده و محدوده برداشت در اين تحقيق بسيار نزديك بوده و از

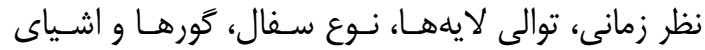

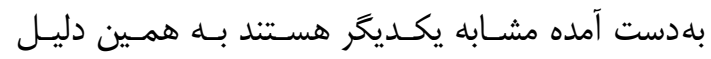

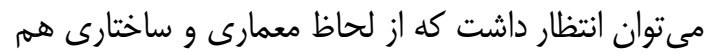

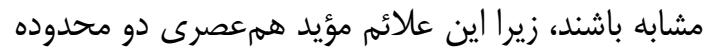

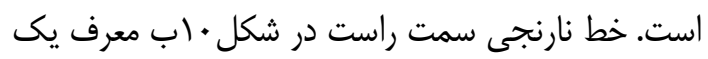
كوجه باستانى است. با تلفيق نتايج بالا مىتوان يك نماى كلى از وضعيت منطقه موردمطالعه به دست آورد كه وضعيت اين كوجهانها

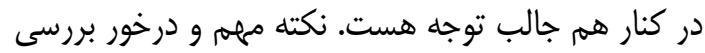

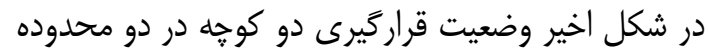

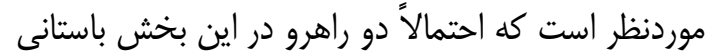

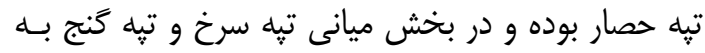

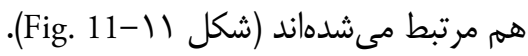

\section{و. ونتيجهكيرى}

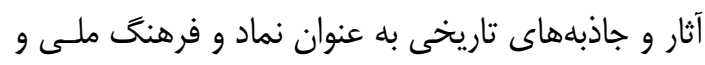
قومى اهميت فراوانى داشته و حفظ و مرمت آنها بها حائز
مغناطيدگى (Magnitization) بالاى محوطه عـالاوه بر دلايل مطروحه باستان شناسى به دليل وجود سنگ إنهاى

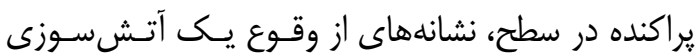

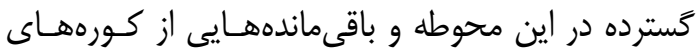
ذوب فلز بلهضوص مس كه در محوطه كسترده شده، نيز

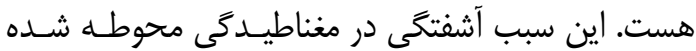
است كه كار را براى تفسير دادهها مشكلتر كرده اسـت.

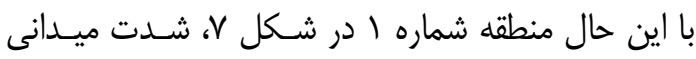

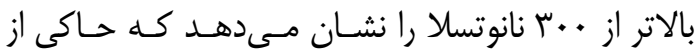

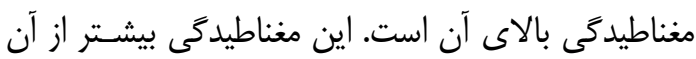

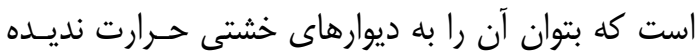

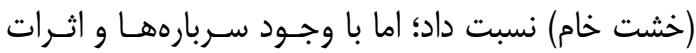
آتشسوزى كه در ديوارهى ضلع شـمالى كمانـه حفـارى

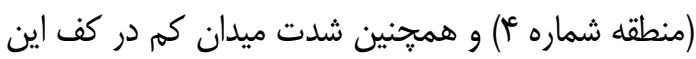

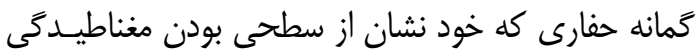

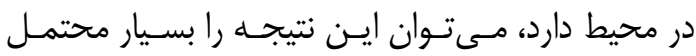

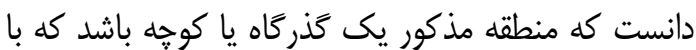
خاكهاى سطحى، سنگ

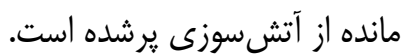
كوجِهاى باستانى با شكل هندسى نامنظم است كه

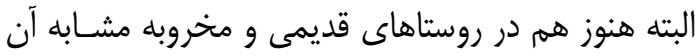

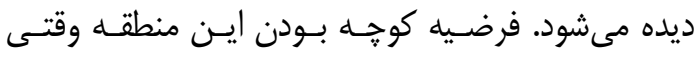

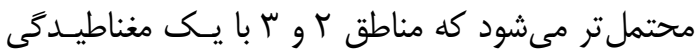
متوسط كه مىتوان بيشتر آن را ناشى از سازهان مهاى خشتى

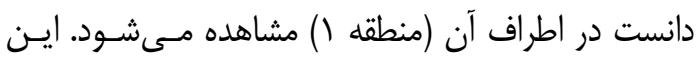

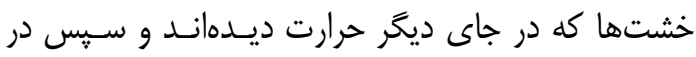

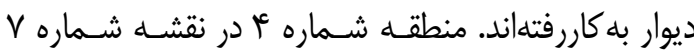

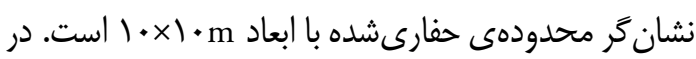
آن קند اتاقك وجود دارد كه در عمليات كرانى سنجى بنا

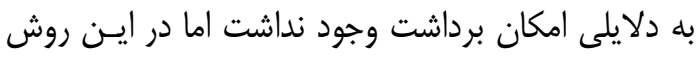

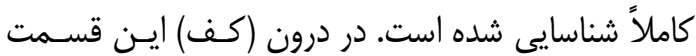
شدت ميدان مغناطيسى كم است و اين نشان مى دهد كه اين مغناطيدگى بالا در اين محوطه سطحى است ون و و تقريباً

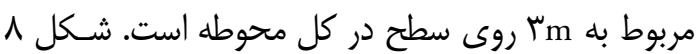

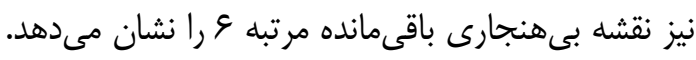

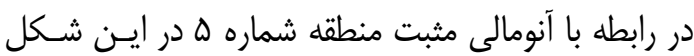
اكر جهه با قاطعيت نمى توان اظهارنظر كرد اما با توجـهـ بــهـ

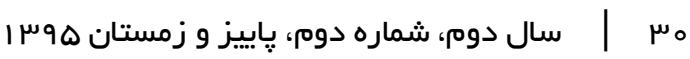




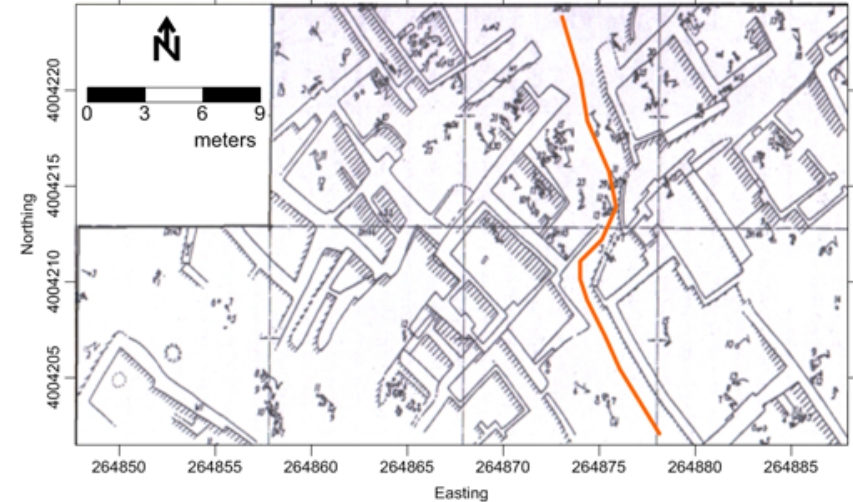

(b)

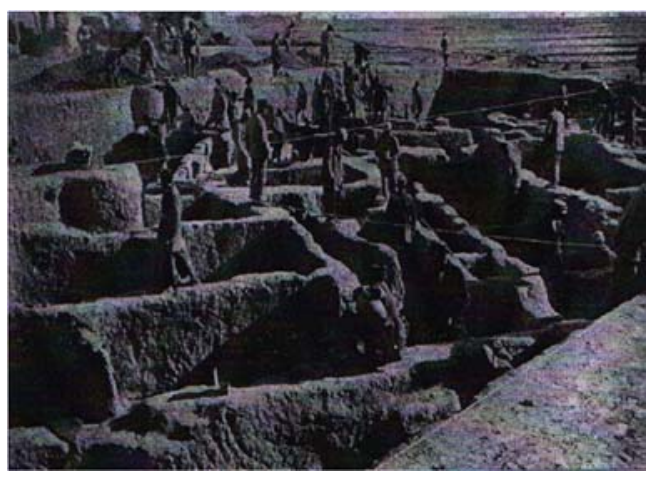

(a)

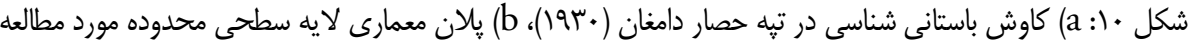

Fig. 10: a) Archaeological excavations in Tepe Hissar, Damghan (1930), b) the surface layer of the architectural plan in study area (Roustaei, 2010)

حاصل از آن با نقشههاى حاصل از عمليات كرانىسنجى

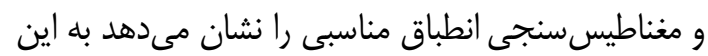

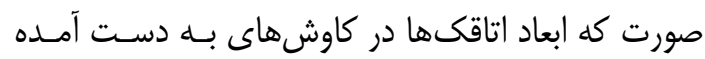

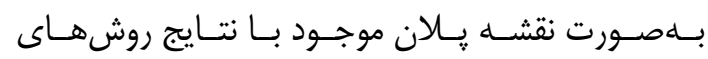

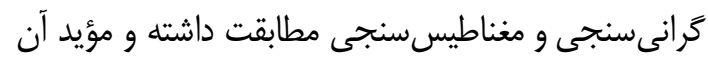
است. با توجه به اينكه عمليات كاوش هزينهابر، وقت كائير و و

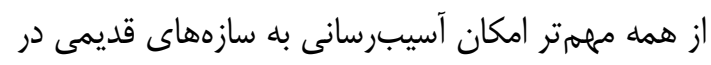

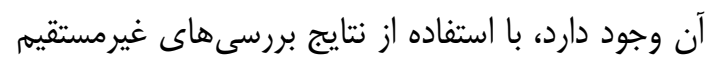

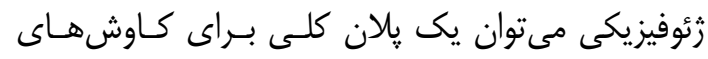

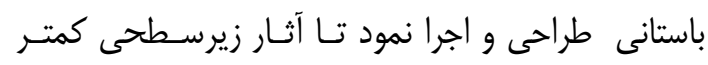

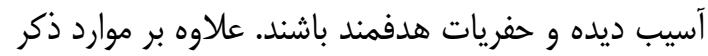

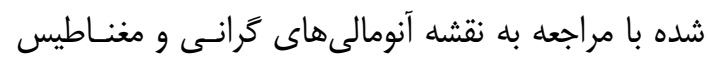

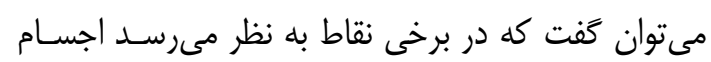

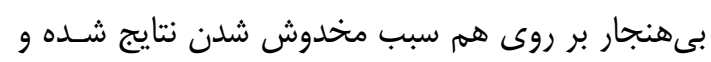
در نتيجه سبب عدم تفكيك خوب ساختارها شـده اسـتـ

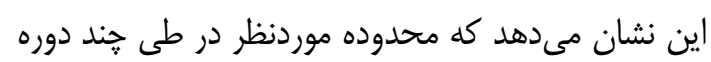

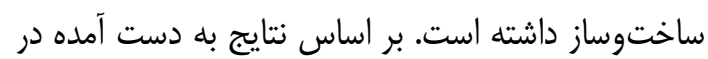
اين تحقيق، به منظور جستجو و كاوش بيشتر در محوطه

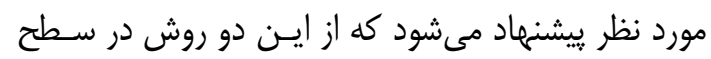

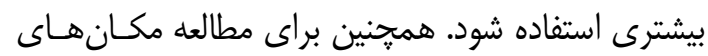

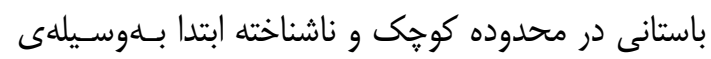

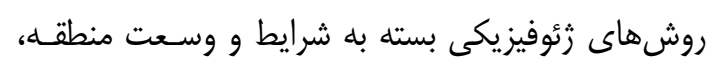
عمليات شناسايى اوليه انجام شود تا با صرف هزينه كمتر مناسبترين نقاط براى حفارى تعيين شود.
اهميت است. شناسايى اين گَونه آثار در منـاطق باسـتانى

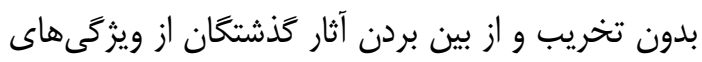

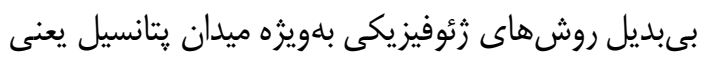

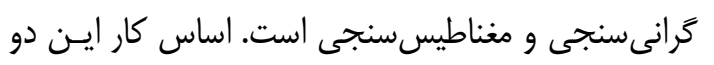

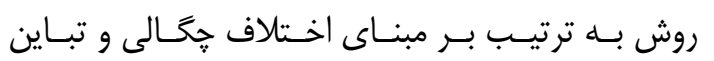

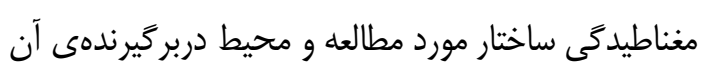

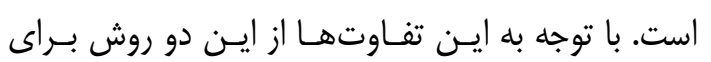

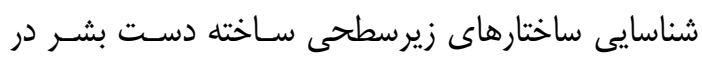

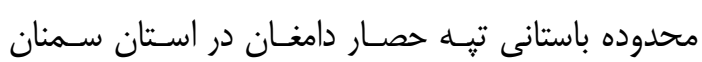

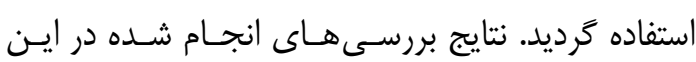

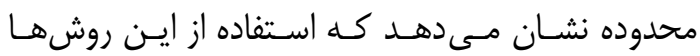

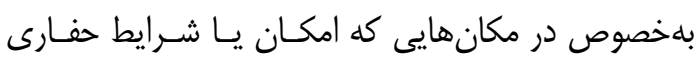

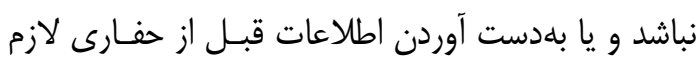
باشد بسيار مفيد است. نتايج بررسى زئوفيزيكى در محوطه

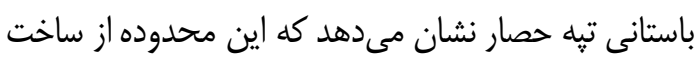

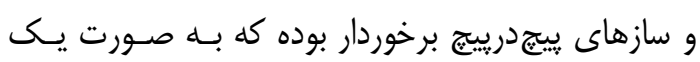

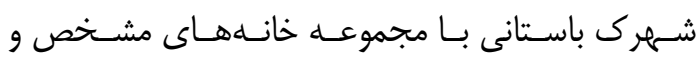

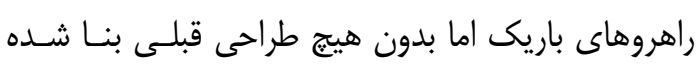

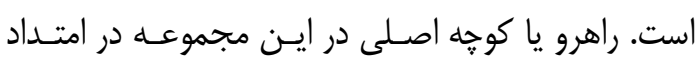

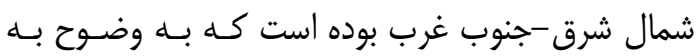

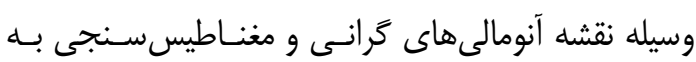
دليل تغيير در ماهيت مواد زيرسطحى در تبه حصار قابـل نوانل مشاهده و يييخيرى است. مقايسه نتايج حفارى در اين محوطـه و نقشـهـهـاى 

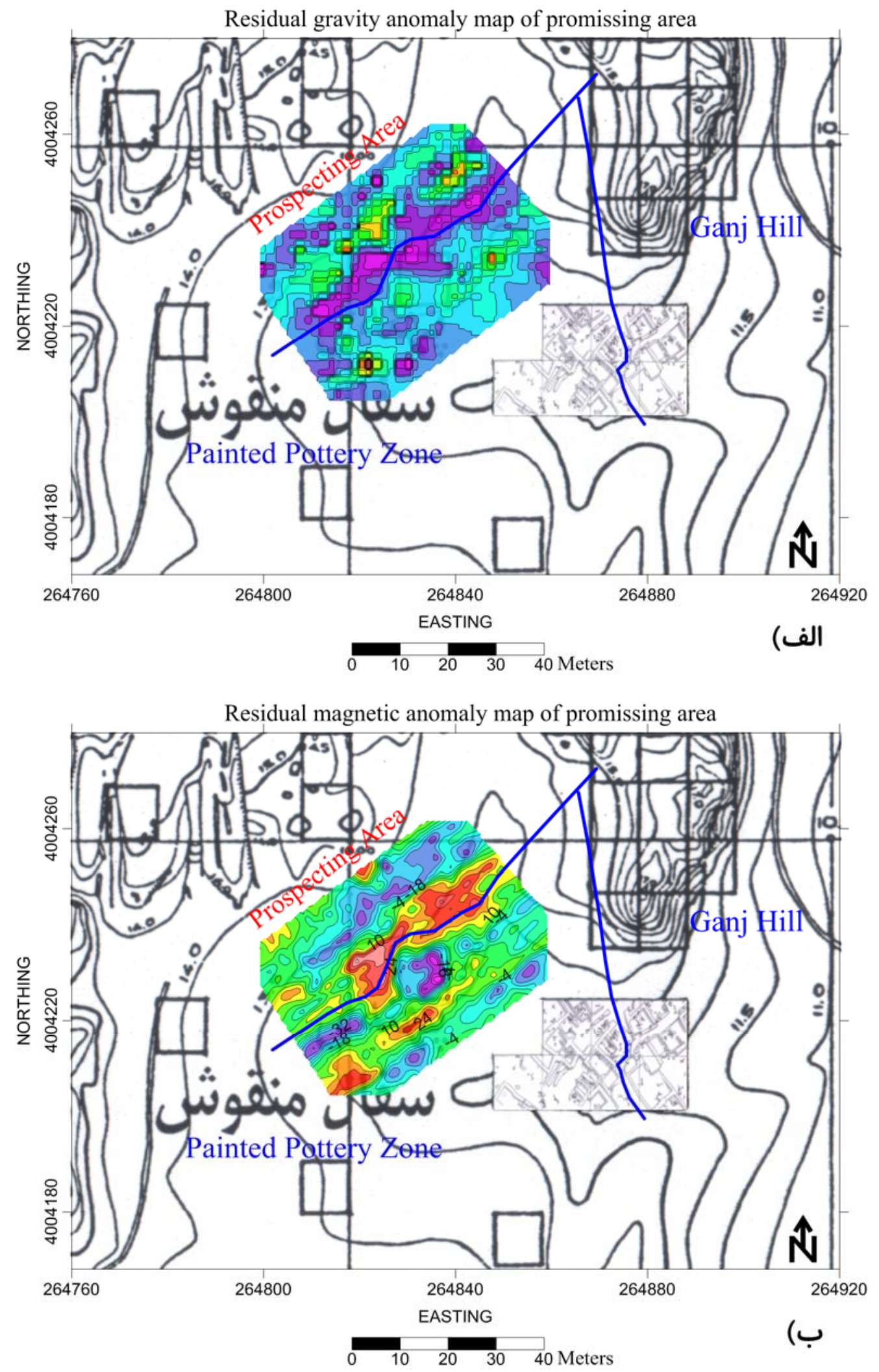

شكل (1: مقايسه نتايج به دست آمده از مطالعات زئوفيزيك با كاوشهاى انجام شده در تيه حصار در سال .

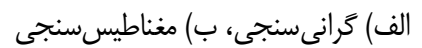

Fig. 11: Comparison of the results obtained from geophysical studies respect to excavations results on the Tepe Hissar in 1930, A) gravimetry, B) magnetometry 
دادن دستخاههاى گرانىسنج و مغناطيسســنج صـميمانه

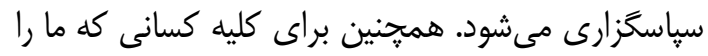
در اجراى اين كار يارى دادند سلامتى و توفيق روزافزون

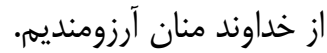

\section{References}

Ahmadpour, A., Kamkar-Rouhani, A. and Ahmadi, R. (2017). Archaeological Exploration of Tappeh Hissar, Damghan Using Forward and Inverse Modeling of Ground-Penetrating Radar Data. Journal of Research on Archaeometry, 2(1), 1-16. [in Persian with English abstract].

Aitken, M. J. (1959). Magnetic prospecting: An interim assessment. Antiquity, 33(131), 205-208.

AliTajer, S., and Afshari Azad, S. (2013). Investigating the Role of Geomatics Engineering in the Applications of Cultural Heritage, Archeology and Architecture. Journal of Archaeological Researches in Iran, 5, 169-195. [in Persian with English abstract].

Alldred, J. C. (1964). A fluxgate gradiometer for archaeological surveying. Archaeometry, 7(1), 1419.

Aminpour, B. (2001). Application of Geophysics methods in archeology and an example of the implementation of the magnetic method in around of Chgharznbyl Temple. Journal History: Ancient Research, 8, 6-9. [in Persian].

Aspinall, A., Gaffney, C. F., \& Schmidt, A. R. (2008). Magnetometry for Archaeologists. United Kingdom: AltaMira Pres.

Batayneh, A., Khataibeh, J., Alrshdan, H., Tobasi, U., \& Al-Jahed, N. (2007). The use of microgravity, magnetometry and resistivity surveys for the characterization and preservation of an archaeological site at Umm er-Rasas, Jordan. Archaeological Prospection, 14(1), 60-70.

Bevan, B. W. (1994). The magnetic anomaly of a brick foundation. Archaeological Prospection, 1(2), 93-104.

Bishop, I., Styles, P., Emsley, S. J., \& Ferguson, N. S. (1997). The detection of cavities using the microgravity technique: case histories from mining and karstic environments. Geological Society, London, Engineering Geology Special Publications, 12(1), 153-166.

Castiello, G., Florio, G., Grimaldi, M., \& Fedi, M. (2010). Enhanced methods for interpreting microgravity anomalies in urban areas. first break,
28(8).

Clark, O. A., \& Clark, A. (2003). Seeing beneath the soil: prospecting methods in archaeology. Routledge.

Fassbinder, J. W., Stanjek, H., \& Vali, H. (1990). Occurrence of magnetic bacteria in soil. Nature, 343(6254), 161.

Gaffney, C. F., Gater, J. A., Linford, P., Gaffney, V. L., \& White, R. (2000). Large-scale systematic fluxgate gradiometry at the Roman city of Wroxeter. Archaeological Prospection, 7(2), 81-99.

Hesse, A., Barba, L., Link, K., \& Ortiz, A. (1997). A magnetic and electrical study of archaeological structures at Loma Alta, Michoacan, Mexico. Archaeological Prospection, 4(2), 53-67.

Linford, N. (2006). The application of geophysical methods to archaeological prospection. Reports on progress in physics, 69(7), 2205.

Linington, R. E. (1966). Test use of a gravimeter on Etruscan chamber tombs at Cerveteri. Prospezioni Archeologiche, 1, 37-41.

Miller, H. G., \& Singh, V. (1994). Potential field tilt-a new concept for location of potential field sources. Journal of Applied Geophysics, 32(2-3), 213-217.

Mohammadkhani, K. (2004). Geophysical exploration methods in archeology case study, magnetometry in Takht-Jamshid and Pasargad (Unpublished master's thesis). Tarbiat Modares University. [in Persian].

Pánisová, J., \& Pašteka, R. (2009). The use of microgravity technique in archaeology: A case study from the St. Nicolas Church in Pukanec, Slovakia. Contributions to Geophysics and Geodesy, 39(3), 237-254.

Roustaei, K. (2010). Tappeh Hesar: Once Again. Proceedings of the Sixth International Congress on Archaeology of the Ancient Near East, May $5^{\text {th }} 8^{\text {th }}$ 2008, Sapienza, Universita di Roma, Volume 2, Excavations, Surveys and Restorations: Reports on Recent Field Archaeology in the Near East, In P. Matthiae, F. Pinnock, L. Nigro and N. Marchetti (Eds.), Wiesbaden: Harrasowitz Verlag, 613-633. 
Schmidt, E. F., \& Kimball, F. (1937). Excavations at Tepe Hissar, Damghan. University Museum.

Slepak, Z. (1999). Electromagnetic sounding and high-precision gravimeter survey define ancient stone building remains in the territory of Kazan Kremlin (Kazan, Republic of Tatarstan, Russia). Archaeological Prospection, 6(3), 147-160.
Telford, W. M., Geldart, L. P., and Sheriff, R. E. (1990). Applied geophysics (Vol. 1). Cambridge university press.

Tite, M. S., \& Mullins, C. (1971). Enhancement of the magnetic susceptibility of soils on archaeological sites. Archaeometry, 13(2), 209219. 